\title{
Oxidation of North Dakota Scrubber Sludge for Soil Amendment and Production of Gypsum
}

Final Report

October 1997

\author{
By: \\ David J. Hassett \\ Thomas A. Moe
}

Work Performed Under Contract No.: DE-FC21-93MC30098

\author{
For \\ U.S. Department of Energy \\ Office of Fossil Energy \\ Federal Energy Technology Center \\ P.O. Box 880 \\ Morgantown, West Virginia 26507-0880
}

By

Energy \& Environmental Research Center

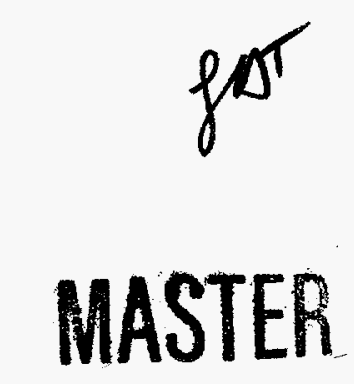

University of North Dakota

P. O. Box 9018

Grand Forks, North Dakota 58202-9018 


\section{Disclaimer}

This report was prepared as an account of work sponsored by an agency of the United States Government. Neither the United States Government nor any agency thereof, nor any of their employees, makes any warranty, express or implied, or assumes any legal liability or responsibility for the accuracy, completeness, or usefulness of any information, apparatus, product, or process disclosed, or represents that its use would not infringe privately owned rights. Reference herein to any specific commercial product, process, or service by trade name, trademark, manufacturer, or otherwise does not necessarily constitute or imply its endorsement, recommendation, or favoring by the United States Government or any agency thereof. The views and opinions of authors expressed herein do not necessarily state or reflect those of the United States Government or any agency thereof. 


\section{DISCLAIMER}

Portions of this document may be illegible in electronic image products. Images are produced from the best available original document. 
LIST OF FIGURES $\ldots \ldots \ldots \ldots \ldots \ldots \ldots \ldots \ldots \ldots \ldots \ldots \ldots \ldots \ldots \ldots \ldots \ldots \ldots$

LIST OF TABLES $\ldots \ldots \ldots \ldots \ldots \ldots \ldots \ldots \ldots \ldots \ldots \ldots \ldots \ldots \ldots \ldots \ldots \ldots$

EXECUTIVE SUMMARY $\ldots \ldots \ldots \ldots \ldots \ldots \ldots \ldots \ldots \ldots \ldots \ldots$ iii

INTRODUCTION $\ldots \ldots \ldots \ldots \ldots \ldots \ldots \ldots \ldots \ldots \ldots \ldots \ldots \ldots \ldots \ldots \ldots$

BACKGROUND $\ldots \ldots \ldots \ldots \ldots \ldots \ldots \ldots \ldots \ldots \ldots \ldots \ldots \ldots \ldots \ldots \ldots$

GOALS AND OBJECTIVES $\ldots \ldots \ldots \ldots \ldots \ldots \ldots \ldots \ldots \ldots \ldots \ldots \ldots \ldots$

EXPERIMENTAL ....................... 3

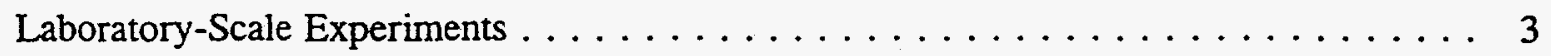

Pilot-Scale Experiments . . . . . . . . . . . . . . . . 5

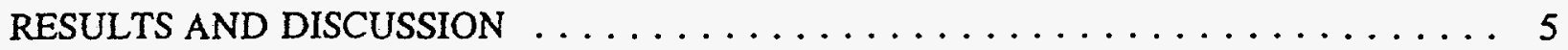

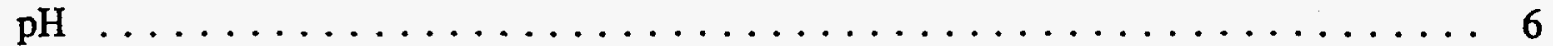

Use of Iron and Manganese Catalysts $\ldots \ldots \ldots \ldots \ldots \ldots \ldots \ldots \ldots \ldots \ldots \ldots \ldots \ldots$

Oxidation at Elevated Temperature . . . . . . . . . . . . . . . 7

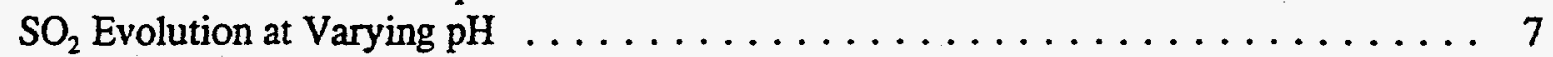

Trace Element Partitioning $\ldots \ldots \ldots \ldots \ldots \ldots \ldots \ldots \ldots \ldots \ldots \ldots$

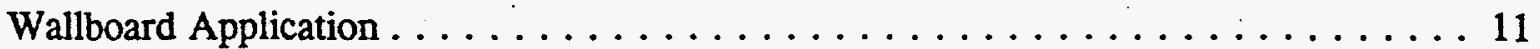

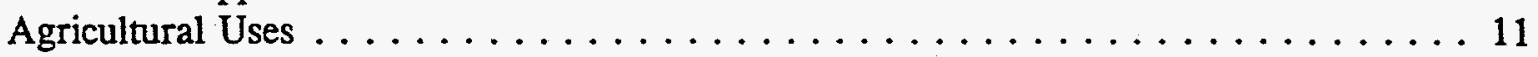

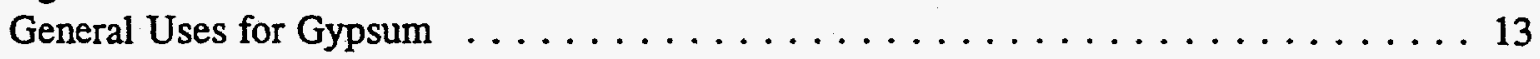

FULL-SCALE GYPSUM PRODUCTION $\ldots \ldots \ldots \ldots \ldots \ldots \ldots \ldots \ldots \ldots \ldots$

CONCLUSIONS AND RECOMMENDATIONS $\ldots \ldots \ldots \ldots \ldots \ldots \ldots \ldots \ldots$

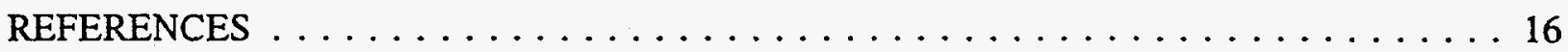

DESCRIPTION OF THE PILOT-SCALE DEMONSTRATION $\ldots \ldots \ldots \ldots$ Appendix A

SELECTED BIBLIOGRAPHY $\ldots \ldots \ldots \ldots \ldots \ldots \ldots \ldots \ldots \ldots \ldots \ldots \ldots \ldots \ldots \ldots$ Appendix B

EQUIPMENT AND COST ESTIMATES FOR PROCESS SCALE-UP $\ldots \ldots \ldots$ Appendix C 


\section{LIST OF FIGURES}

1 Oxidation of scrubber sludge at two $\mathrm{pH}$ levels $\ldots \ldots \ldots \ldots$

2 Catalytic oxidation of North Dakota scrubber sludge $\ldots \ldots \ldots \ldots \ldots$

$3 \quad \mathrm{SO}_{2}$ evolution versus $\mathrm{pH} \ldots \ldots \ldots \ldots \ldots \ldots \ldots \ldots$

\section{LIST OF TABLES}

1 Chemical Analysis of Scrubber Sludge . . . . . . . . . . . . . . 9

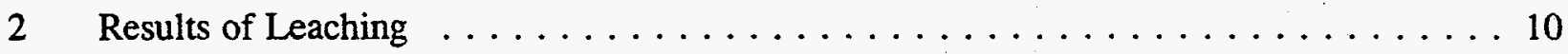

3 Specifications for Gypsum Wallboard Use $\ldots \ldots \ldots \ldots \ldots \ldots \ldots$

4 Summary of CCB Production and Use in the United States. . . . . . . . . . 13

5 Summary of FGD Use in the United States. . . . . . . . . . . . . 13 


\section{OXIDATION OF NORTH DAKOTA SCRUBBER SLUDGE FOR SOIL AMENDMENT AND PRODUCTION OF GYPSUM}

\section{EXECUTIVE SUMMARY}

Cooperative Power's Coal Creek Station (CCS) has successfully marketed its fly ash for commercial use, and Cooperative Power has been an industry proponent of CCB utilization since CCS became operational in 1981. With awareness of the economic and environmental advantages of by-product utilization, the favorable U.S. Environmental Protection Agency (EPA) regulatory determination that CCBs are not hazardous, and the improved understanding of potential local and regional markets, Cooperative Power initiated an investigation on processing and utilization of CCS scrubber sludge. Cooperative Power, the North Dakota Industrial Commission, and the U.S. Department of Energy provided funds for a research project at the Energy \& Environmental Research Center. The goals of the project were 1) to determine conditions for the conversion of scrubber sludge to gypsum simulating an ex situ process on the laboratory scale;2) to determine the feasibility of scaleup of the process; 3 ) if warranted, to demonstrate the ex situ process for conversion on the pilot scale; and 4) to evaluate the quality and handling characteristics of the gypsum produced on the pilot scale.

The process development and demonstration phases of this project were successfully completed focusing on ex situ oxidation using air at low $\mathrm{pH}$. The potential to produce a high-purity gypsum on a commercial scale is excellent. A relatively extensive evaluation of the pilot-scale flue gas desulfurization (FGD) gypsum product was performed to facilitate the marketing effort for this material in a broad range of applications, including agricultural uses. During the course of this evaluation, it was noted that some trace elements were present in measurable quantities in the FGD gypsum. These elements were mercury, chromium, and chlorine (present as chloride). Although they were present in measurable amcunts, it is important to note that the mercury and chromium were present at very low levels, with leachate concentrations less than the primary drinking water standard levels. Air oxidation of scrubber sludge was carried out in laboratory- and pilot-scale operations. Initial experiments to provide information on efficiency of oxidation, most favorable reaction conditions (particularly $\mathrm{pH}$ ), and other reaction variables such as air flow rates and the effects of iron and manganese catalysts were carried out in a five-necked 500-mL Pyrex reaction flask. The laboratory-scale experiments indicated that the reaction was rapid and complete and thus ideal for scaleup. The pilot-scale oxidation was carried out in a 500-gal stainless steel tank. All reaction conditions were maintained at optimum as determined in the laboratory studies with $\mathrm{pH}$ controlled to between 4.5 and 5.0 by' adding $20 \%$ sulfuric acid as required.

The results of this project demonstrate the feasibility of converting CCS scrubber sludge to gypsum exhibiting characteristics appropriate for agricultural application as soil amendment as well as for use in gypsum wallboard prociuction. Gypsum of a purity of over $98 \%$ containing acceptable levels of potentially problematic constituents was produced in the laboratory and in a pilot-scale demonstration. 


\section{OXIDATION OF NORTH DAKOTA SCRUBBER SLUDGE \\ FOR SOIL AMENDMENT AND PRODUCTION OF GYPSUM}

\section{INTRODUCTION}

The use of scrubber sludge has traditionally been limited for a variety of reasons; however, the chemical and mineralogical composition of these materials shows promise for several applications. This research project evaluated and demonstrated the use of ex situ air oxidation of scrubber sludge from a single North Dakota source to produce calcium sulfate dihydrate (gypsum) for potential use in gypsum wallboard and other gypsum products and for agricultural soil amendment.

The requirements and standards for gypsum vary according to the applications for which it is typically used. The applications of greatest interest to Cooperative Power for regional commercial marketing were wallboard production and agricultural soil amendment. For wallboard use, mineralogy, particle size, and major/minor element concentrations are important. The prime considerations for wallboard applications are suitability for production of material with sufficient strength for wallboard manufacture and appearance. For agricultural soil amendment, the presence of trace elements and unoxidized sulfite is most important because of possible toxicity to plants as well as the potential for accumulation of potentially toxic trace elements in products intended for consumption by animals or humans. In agricultural use, the permissible amounts of potentially problematic constituents can be a variable dependent on what crops will be grown and the rate and/ or frequency of application. Further complicating the use of gypsum in agriculture is the fact that some trace elements, such as boron and selenium, are problematic in both high and low concentrations. Boron is an essential plant nutrient that can also be phytotoxic at high levels, while selenium is an essential nutrient for humans that also possess toxic properties at excessive dose levels. For these and other trace elements, the aspect of toxicity is often a function of concentration or dose rather than identity.

Cooperative Power has a strong commitment to utilization of the lignite by-products generated at Coal Creek Station (CCS) near Underwood, North Dakota, and they initiated an investigation on processing and utilization of CCS scrubber sludge. Cooperative Power, the North Dakota Industrial Commission, and the U.S. Department of Energy (DOE) provided funds for a research project at the Energy \& Environmental Research Center (EERC) to perform the required work to evaluate the potential for gypsum production from CCS scrubber sludge. The EERC focused on the development and demonstration of gypsum production through ex situ forced oxidation of the wet flue gas desulfurization (FGD) material, scrubber sludge, produced as a result of sulfur emissions control at the CCS power plant.

\section{BACKGROUND}

Coal Creek Station's FGD process uses hydrated lime to scrub $\mathrm{SO}_{2}$ emissions and produces a material that is primarily a calcium sulfite slurry. The raw scrubber sludge contains over $80 \%$ water. It was decided early on that ex situ oxidation, which requires minimal equipment modification, would be the method of choice for gypsum production. In situ forced oxidation, 
which uses air addition to the scrubber to form gypsum directly in the scrubber tower, requires significant equipment modification. Although this method might appear superior for gypsum production in terms of overall simplicity, the implications of trace elements in agricultural applications and the need for high-purity calcium sulfate for wallboard applications make ex situ oxidation an attractive choice. The reasons for this are discussed in detail in the text of this report. follows:

The reactions involved in $\mathrm{SO}_{2}$ :emoval in a lime-based scrubber can be summarized as

Dissolution of $\mathrm{SO}_{2}$ :

$$
\mathrm{SO}_{2}+\mathrm{H}_{2} \mathrm{O} \rightarrow 2 \mathrm{H}^{+}(\mathrm{aq})+\mathrm{SO}_{3}^{2-}(\mathrm{aq})
$$

Hydration of lime:

$$
\mathrm{CaO}+\mathrm{H}_{2} \mathrm{O} \rightarrow \mathrm{Ca}(\mathrm{OH})_{2}
$$

Dissolution of hydrated lime:

$$
\mathrm{Ca}(\mathrm{OH})_{2}(\mathrm{aq} \text { slurry })-\mathrm{Ca}^{2+}(\mathrm{aq})+2 \mathrm{OH}^{-}(\mathrm{aq})
$$

Reactions of dissolved $\mathrm{SO}_{2}$ with dissolved hydrated lime:

$$
\mathrm{Ca}^{2+}+\mathrm{SO}_{3}^{2-}+2 \mathrm{OH}^{-}+2 \mathrm{H}^{+}-\mathrm{CaSO}_{3} \cdot 1 / 2 \mathrm{H}_{2} \mathrm{O}+3 / 2 \mathrm{H}_{2} \mathrm{O}
$$

The following reactions also can be txpected:

$$
\begin{gathered}
\mathrm{Ca}^{2+}+2 \mathrm{OH}^{-}+2 \mathrm{HCl} \rightarrow \mathrm{Ca}^{2+}+2 \mathrm{Cl}^{-}+2 \mathrm{H}_{2} \mathrm{O} \\
\mathrm{CO}_{2}+\mathrm{H}_{2} \mathrm{O}=\mathrm{H}_{2} \mathrm{CO}_{3} \\
\mathrm{Ca}^{2+}+2 \mathrm{OH}^{-}+\mathrm{H}_{2} \mathrm{O}+\mathrm{CO}_{2} \rightarrow \mathrm{CaCO}_{3}+2 \mathrm{H}_{2} \mathrm{O}
\end{gathered}
$$

In the case of a scrubber utilizing a strong base such as hydrated lime, the reaction with sulfur dioxide, which is a weak acid anhydride (sulfurous acid, $\mathrm{H}_{2} \mathrm{SO}_{3}$ ) is complete and rapid in aqueous solution. The resultant product as shown in Equation 4 above is calcium sulfite hemihydrate (hannebachite). The only additional product of the reaction is water from the neutralization of the calcium hydroxide during the scrubbing process. Since calcium hydroxide is a strong base, it tends to react with any acidic gas or gaseous acid anhydride such as hydrogen chloride $(\mathrm{HCl})$, hydrogen fluoride (HF) or even carbon dioxide, as shown in Equations 5 and 7. Thus chloride incorporated into scrubber sludge from the neutralization of $\mathrm{HCl}$ formed during combustion as well as calcium carbonate can be expected to be components of scrubber sludge.

The process development and demonstration phases of this project were successfully completed focusing on ex situ oxidation using air at low $\mathrm{pH}$ and demonstrated the potential to produce a high-purity gypsum on a commercial scale. A relatively extensive evaluation of the pilot- 
scale FGD gypsum product was performed to facilitate the marketing effort for this material in a broad range of applications, including agricultural uses. During the course of this evaluation, it was noted that some trace elements were present in measurable quantities in the FGD gypsum. These elements were mercury, chromium, and chlorine (present as chloride), and although they were present in measurable amounts, it is important to note that the mercury and chromium were present at very low levels, with leachate concentrations less than the primary drinking water standard levels. Although it was known from previous analyses that trace elements were present in the wet FGD material, it was anticipated that the oxidation process used would facilitate the removal of "contaminants," especially since the FGD gypsum was washed postproduction. In follow-up work, solid materials, reaction waters, and leachate were all analyzed in an effort to determine the fate of these trace constituents relative to the FGD gypsum produced using the air oxidation process.

\section{GOAL AND OBJECTIVES}

The overall project goal was to determine the feasibility of converting CCS scrubber sludge to gypsum for commercial utilization. The supporting objectives were 1) to determine the conditions for conversion of scrubber sludge to gypsum simulating an ex situ process on a laboratory scale; 2 ) to determine the feasibility of scaleup of the process; 3 ) if warranted, to demonstrate the ex situ process for conversion on the pilot scale; and 4) to evaluate the quality and handling characteristics of the gypsum produced on the pilot scale. The laboratory-and pilot-scale experiments were developed to provide information to achieve the stated goal and objectives.

\section{EXPERIMENTAL}

Air oxidation of scrubber sludge was carried out in laboratory- and pilot-scale operations. Initial experiments to provide information on efficiency of oxidation, most favorable reaction conditions (particularly $\mathrm{pH}$ ), and other reaction variables such as air flow rates and the effects of iron and manganese catalysts were carried out in a five-necked 500-mL Pyrex reaction flask. The flask was equipped with a constant-velocity stirrer; outfitted for the addition of acid (10\% sulfuric

acid), the addition of air, and venting of the flask to a stack gas analyzer for the determination of $\mathrm{SO}_{2}$; and an additional port reserved for removal of samples to determine completeness of conversion of sulfite to sulfate. Oxidation was carried out at between $\mathrm{pH} 4$ and 5 . The scrubber sludge provided to us was a relatively pure suspension of calcium sulfite hemihydrate (hannebachite) containing some unreacted calcium hydroxide and some associated calcium carbonate. The mineralogical composition of the scrubber sludge was determined using $x$-ray diffraction (XRD), while the determination of sulfite content was made using an iodometric titration. The laboratory-scale experiments indicated that the reaction was rapid and complete and thus ideal for scaleup.

\section{Laboratory-Scale Experiments}

$500 \mathrm{~mL}$ of well-mixed unoxidized scrubber sludge was placed into the reaction assembly described above. Stirring was started, and $10 \%$ sulfuric acid was added with a peristaltic pump. Pump speed was adjusted to maintain the desired $\mathrm{pH}$ for the experiment currently under way. Most experiments required the addition of between 16 and $20 \mathrm{~mL}$ of acid during the course of the air 
oxidation experiment. To achieve this addition and maintain $\mathrm{pH}$ in the desired range of 4-5, a flow rate of approximately $0.05 \mathrm{~mL} / \mathrm{min}$ was used. This assured delivery of the required amount of acid over a time frame somewhat less thin the 7 to $9 \mathrm{hr}$ required for complete oxidation in the lab experiments. An adjustable-flow peristaltic pump was used to allow addition of acid as necessary to maintain $\mathrm{pH}$ at the desired level. $\mathrm{pH}$ : was constantly monitored and for the lab experiments, manual adjustment of acid flow was used to maintain the desired $\mathrm{pH}$. Air was introduced through a coarseporosity sintered glass diffuser at a rate of 15-16 standard cubic feet (scf) per hour, which is a nominal $7 \mathrm{~L} / \mathrm{mm}$. This was a rather high flow rate for the air but was necessary to keep the frit from plugging and also assured saturation of the solution with air. Samples were removed from the reactor at regular time intervals for determination of sulfite concentration. 1-mL samples were removed at the beginning of the experiment, and sulfite was determined by titrating with standardized iodine to a starch end point. As the amount of iodine required decreased toward the end of the experiment, larger samples were required for meaningful measurement of sulfite. The reaction was deemed to be complete: when a $5-\mathrm{mL}$ sample required less than $1 \mathrm{~mL}$ of iodine. This indicated a greater than $99 \%$ conversion of sulfite to sulfate.

Laboratory-scale experiments focused on the effects of $\mathrm{pH}$ on rate of oxidation and sulfur dioxide emission during air oxidation, and the effects of catalysts such as iron and manganese on scrubber sludge oxidation rates. One experiment was also conducted at an elevated temperature.

Air oxidation of calcium sulfite-containing scrubber sludge can be represented by the following equations, which include the reaction of scrubber sludge components with sulfuric acid added for $\mathrm{pH}$ control:

$$
\begin{gathered}
\mathrm{Ca}(\mathrm{OH})_{2}+\mathrm{H}_{2} \mathrm{SO}_{4}+\mathrm{H}_{2} \mathrm{O}-\mathrm{CaSO}_{4} \cdot 2 \mathrm{H}_{2} \mathrm{O} \\
\mathrm{CaCO}_{3}+\mathrm{H}_{2} \mathrm{SO}_{4}-\mathrm{CaSO}_{4}+\mathrm{CO}_{2}+\mathrm{H}_{2} \mathrm{O} \\
2 \mathrm{CaSO}_{3} \cdot 1 / 2 \mathrm{H}_{2} \mathrm{O}+\mathrm{H}_{2} \mathrm{SO}_{4}-\mathrm{CaSO}_{4} \cdot 2 \mathrm{H}_{2} \mathrm{O}+\mathrm{Ca}\left(\mathrm{HSO}_{3}\right)_{2} \\
\mathrm{Ca}\left(\mathrm{HSO}_{3}\right)_{2}(\mathrm{aq})+\mathrm{O}_{2}(\mathrm{~g})-\mathrm{CaSO}_{4} \cdot 2 \mathrm{H}_{2} \mathrm{O}+\mathrm{SO}_{2} \\
\mathrm{SO}_{2}+\mathrm{H}_{2} \mathrm{O} \rightarrow \mathrm{H}_{2} \mathrm{SO}_{3} \\
\mathrm{CaSO}_{3} \cdot 1 / 2 \mathrm{H}_{2} \mathrm{O}+\mathrm{H}_{2} \mathrm{SO}_{3}-\mathrm{Ca}\left(\mathrm{HSO}_{3}\right)_{2}+1 / 2 \mathrm{H}_{2} \mathrm{O}
\end{gathered}
$$

Note: Since most of the reactions above occur in aqueous solution, water of hydration is assumed to be contributed from excess water in the overall system and is not included in the equations, which may not appear balanced with respect to water.

Equation 10 is especially important, since this shows the formation of calcium bisulfite. Calcium bisulfite is much more water-soluble than calcium sulfite, which can be thought of as insoluble. It is the formation of calcium bisulfite that facilitates the solution chemistry responsible for the oxidation of scrubber sludge to gypsum. It can also be seen from Equations 12 and 13 how $\mathrm{SO}_{2}$ in water, forming sulfurous acid, reacts with calcium sulfite to form calcium bisulfite; thus the formation of bisulfite could also be: accomplished by allowing additional sulfur dioxide to react with the scrubber sludge. There are advantages to the use of sulfuric acid for bisulfite formation and for 
$\mathrm{pH}$ control. These are 1) ease of $\mathrm{pH}$ control and 2) complete reaction of any excess calcium hydroxide or calcium carbonate to calcium sulfate. Drawbacks are the added expense of sulfuric acid along with the problems associated with the handling of a strong acid, which can be hazardous. The use of sulfuric acid for $\mathrm{pH}$ adjustment is in part responsible for the high purity of the gypsum produced from the ex situ air oxidation of scrubber sludge as carried out in this project. Gypsum produced in this manner contains essentially no unreacted calcium sorbent.

\section{Pilot-Scale Experiments}

The pilot-scale oxidation was carried out in a 500-gal stainless-steel tank. All reaction conditions were maintained at the optimum based on laboratory experiments, with $\mathrm{pH}$ controlled to between 4.5 and 5.0 by adding $20 \%$ sulfuric acid as required. Lab experiments were carried out with $\mathrm{pH}$ adjustment using $10 \%$ sulfuric acid; however, to keep volumes of material as low as possible, it was decided to use $20 \%$ sulfuric acid in the pilot-scale production of oxidized scrubber sludge. It was found in the laboratory-scale oxidation that there was up to several $\mathrm{ppm}$ of $\mathrm{SO}_{2}$ in the excess air vented from the reactor; thus offgas was scrubbed through a dilute solution of sodium bicarbonate before venting. The pilot-scale oxidation of scrubber sludge resulted in the production of over $300 \mathrm{~kg}$ of calcium sulfate dihydrate (gypsum) with a purity exceeding $98 \%$. The purity of the final products from pilot- and laboratory-scale experiments was determined using inductively coupled argon plasma (ICAP) spectrometry and XRD, as well as by classical chemical and gravimetric methods for the determination of moisture and residual sulfite content. The gypsum produced in the pilot-scale operation contained $<0.1 \%$ sulfite and $270 \mathrm{ppm}$ of acid-insoluble material. In addition to bulk characterization of major constituents, the oxidized scrubber sludge was analyzed for trace constituents in the solid and liquid phases. Additionally, the oxidized scrubber sludge was analyzed for major, minor, and trace constituents after dewatering and air drying to the dihydrate. Chemical analyses determined that the material had a nominal composition of approximately $23 \%$ calcium and $56 \%$ sulfate and contained approximately $20 \%$ water, as would be expected for calcium sulfate dihydrate of greater than $98 \%$ purity. Pure calcium sulfate dihydrate would have a composition of $23.279 \%$ calcium, $55.795 \%$ sulfate, and $20.927 \%$ water. A complete description of the pilot-scale oxidation is included as Appendix A.

The synthetic gypsum resulting from the pilot-scale experiment was evaluated for its potential to be pelletized. These tests were specifically undertaken to facilitate marketing as an agricultural soil amendment. It was assumed that a soil amendment that could be applied with conventional machinery would be advantageous. It was determined that use of a binder improved the pelletizing process significantly. It was further determined from the limited amount of pellets produced that the pelletized product would allow use with conventional machinery. Results of the pelletizing tests are detailed in Appendix A.

\section{RESULTS AND DISCUSSION}

The following sections describe the laboratory-scale experiments used to investigate the various reaction variables of interest. 
pH

Since the formation of calcium bisulfite is required for the air oxidation of scrubber sludge, $\mathrm{pH}$ adjustment was necessary using dilute sulfuric acid as described above. Experiments were carried out with no $\mathrm{pH}$ adjustment, adjustment to $\mathrm{pH} 4.0-4.1$, and adjustment to 5.0-5.1. The initial experiment with no $\mathrm{pH}$ adjustment was performed and demonstrated an extremely slow rate of oxidation, as expected. After 2.5 hours of reaction time, there was no measurable amount of reduction of sulfite content, and the experiment was terminated. Additional experiments were carried out at reduced $\mathrm{pH}$. The experiment carried out at $\mathrm{pH} 4.0-4.1$ reached completion in approximately $6.5 \mathrm{hr}$, while the experiment carried out at $\mathrm{pH}$ 5.0-5.1 required $9 \mathrm{hr}$ for complete oxidation of sulfite. The results of the reduced $\mathrm{pH}$ experiments are shown in Figure 1.

\section{Use of Iron and Manganese Catalysts}

It has been reported that there can be a strong catalytic and even possible inhibiting effects of transition metals such as iron, manganese and cobalt (Karlson et al., 1985). Experiments were carried out using manganese and iron to determine the potential effect of these metals on the ex situ air oxidation of Coal Creek Scrubber Sludge. Cobalt was not studied because of the cost of this material. Manganese at two concentrations, 1.6 and 3.2 millimolar, and iron at one level, 1.6 millimolar, were used in these experiments. $\mathrm{pH}$ in all of the catalysis experiments was adjusted to 4.0. An accelerating effect was shcwn to be exerted by the manganese, especially at higher levels; however, a complete investigation of the use of catalysts was beyond the scope of this work. Experiments on catalysts were not carried out to completion, but were carried out far enough to establish a rate of reaction and to plot a linear regression line over the data to determine rates of reaction and to estimate the time to complete oxidation. Linear regression lines are plotted in

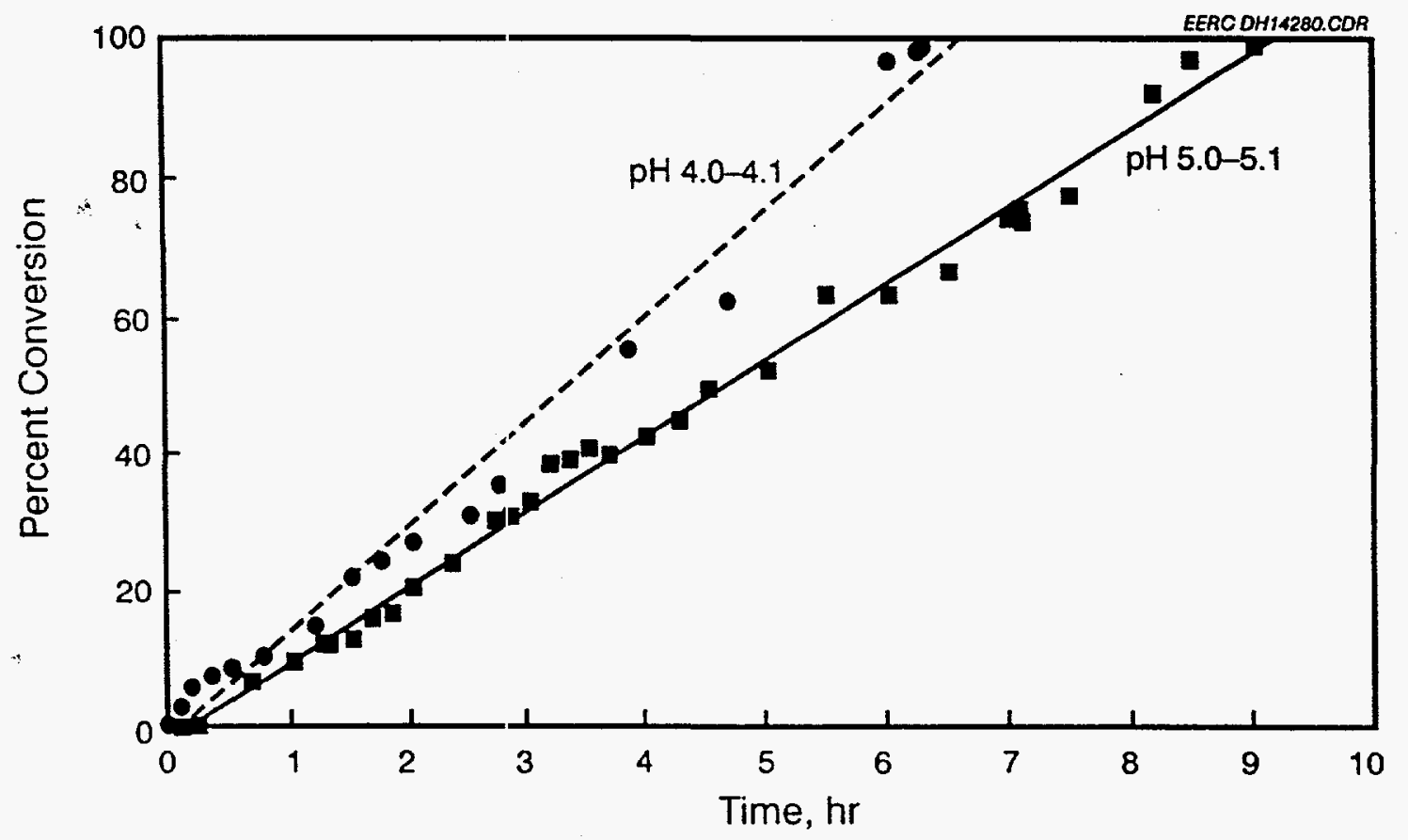

Figure 1. Oxidation of scrubber sludge at two $\mathrm{pH}$ levels. 
Figure 2. It was observed that in the iron-catalyzed experiment, a brown/tan color developed, likely indicating the formation of an iron compound, which may have been an organic complex. In other experiments, it was observed that anaerobic storage led to rapid growth of microorganisms and the development of an undesirable odor.

\section{Oxidation at Elevated Temperature}

One experiment was carried out at an elevated temperature. Oxidation was carried out at $40^{\circ} \mathrm{C}$. This experiment was terminated after $7 \mathrm{hr}$ due to difficulties in keeping the frit from clogging. It was determined experimentally that the advantage of heating, which may have caused a slightly faster reaction rate, was not adequately offset by the difficulty of the frit constantly plugging. This particular difficulty, however, might be overcome by proper engineering design on a larger scale. Based on problems encountered in lab-scale experiments, oxidation at elevated temperature is not recommended.

\section{$\mathrm{SO}_{2}$ Evolution at Varying $\mathrm{pH}$}

It can be seen in equations previously presented that the addition of sulfuric acid results in the formation of bisulfite, and as $\mathrm{pH}$ is further reduced, free $\mathrm{SO}_{2}$ is formed from a chemical equilibrium shifted toward the formation of sulfurous acid rather than bisulfite. From this information, it can be inferred that the lowering of $\mathrm{pH}$ would result in an increase in $\mathrm{SO}_{2}$ concentration in gas vented from the reaction vessel. An experiment was conducted to determine $\mathrm{SO}_{2}$ concentrations in offgas at a constant gas flow rate as $\mathrm{pH}$ was reduced by the addition of sulfuric acid. The data generated in these experiments are shown in Figure 3. It can be seen that

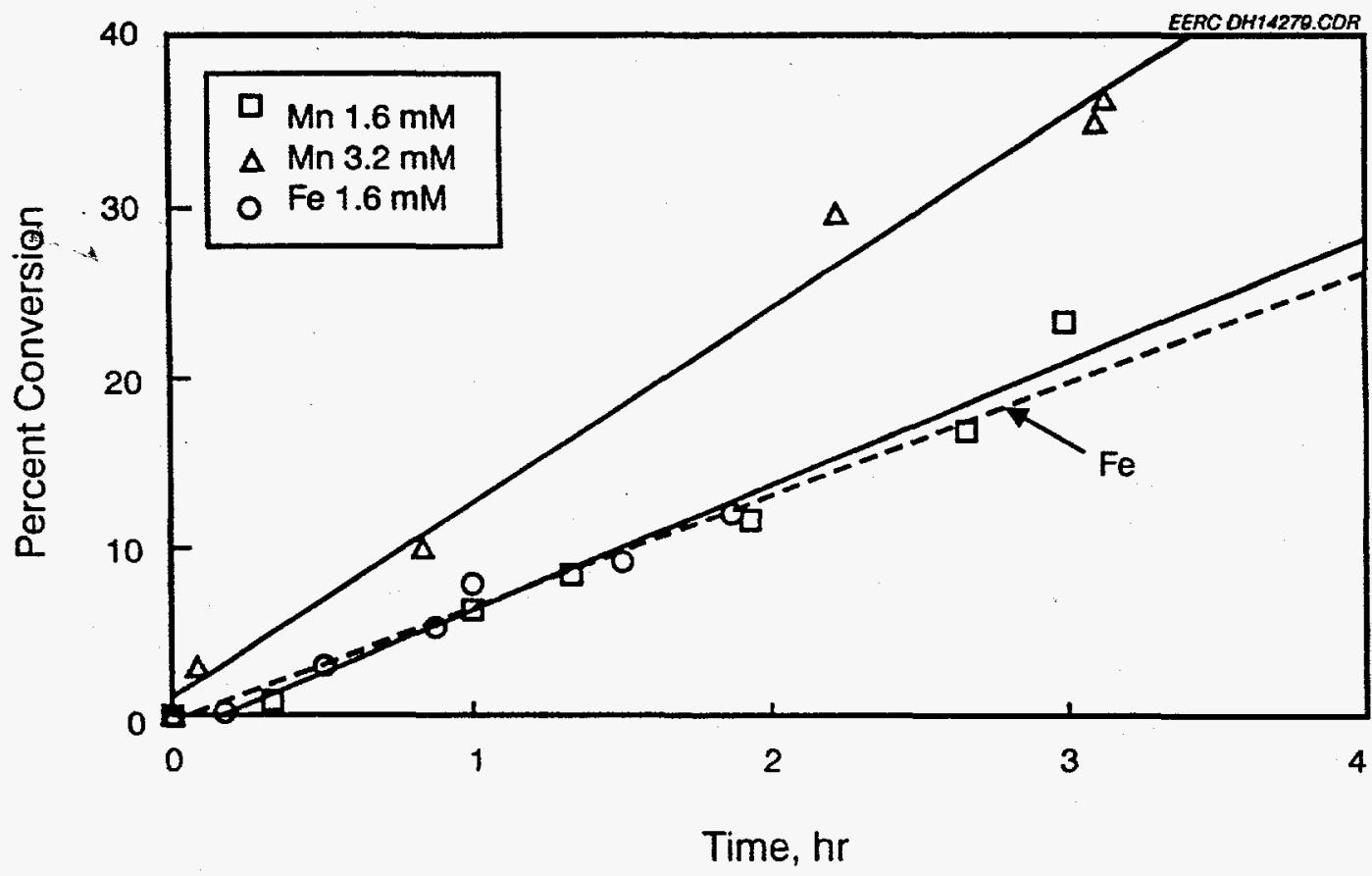

Figure 2. Catalytic oxidation of North Dakota scrubber sludge. 


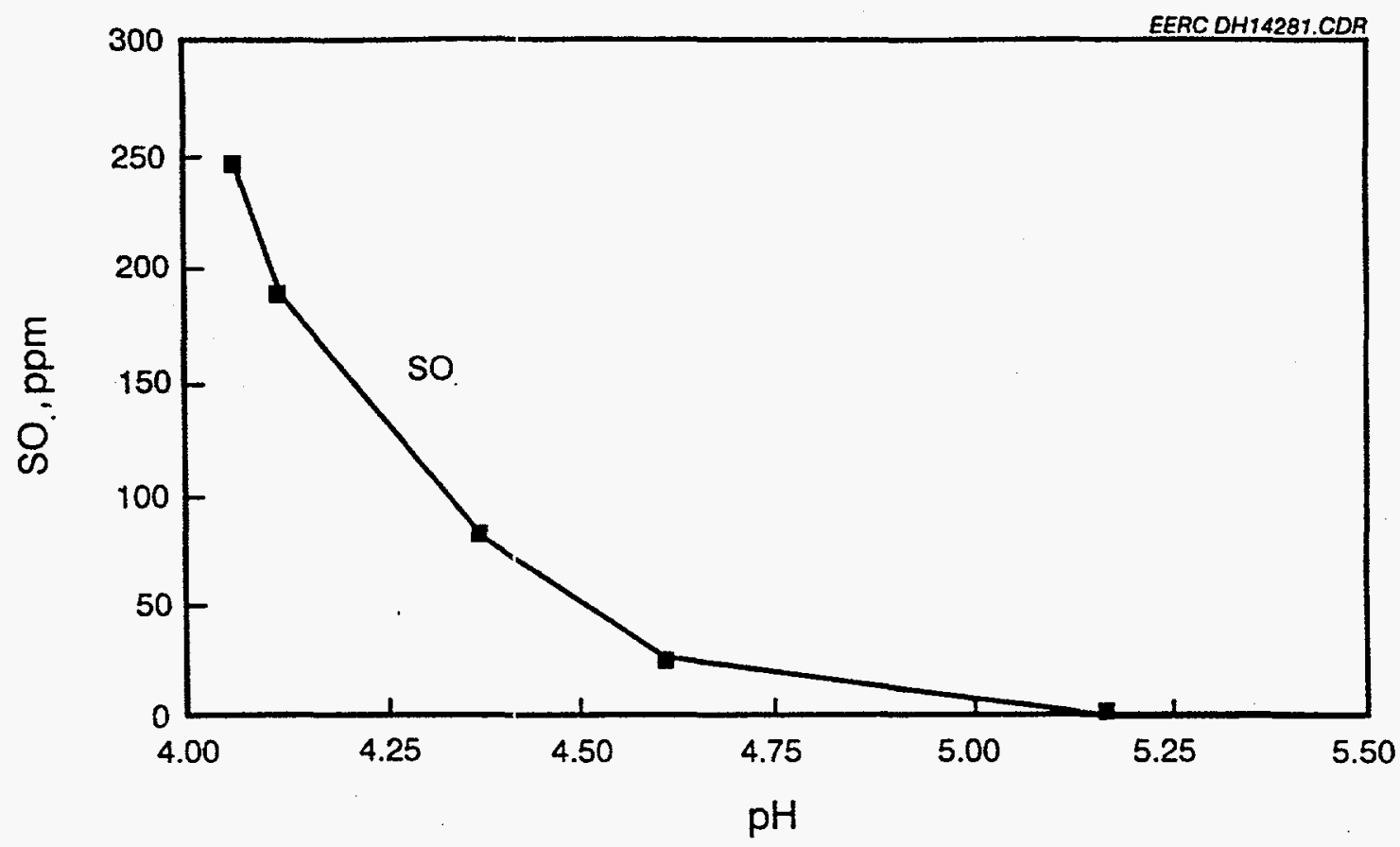

Figure 3. $\mathrm{SO}_{2}$ evolution versus $\mathrm{pH}$.

$\mathrm{SO}_{2}$ concentrations increase from 0 to 1 as $\mathrm{pH}$ is reduced to 5.0-5.2. $\mathrm{SO}_{2}$ concentration increased to $1385 \mathrm{ppm}$ at $\mathrm{pH} 3.2$, although this high value is not included on the plot. This plot clearly illustrates the balance that must be maintained between reaction rate and excessive $\mathrm{SO}_{2}$ offgassing as the $\mathrm{pH}$ of the oxidizing solution is reduced. Oxidation of scrubber sludge may necessitate the scrubbing the offgas to remove $\mathrm{SO}_{2}$.

\section{Trace Element Partitioning}

The recent emphasis by the U.S. Environmental Protection Agency (EPA) on evaluation of trace element emissions from coal-filed utilities and the associated potential for regulation of these emissions pose some interesting questions regarding by-products from these facilities. For those coal-fired utilities that have made a commitment to utilization as an economical and environmentally sound by-product management option, it can be beneficial to understand the relationship and interaction between emissions and by-product streams relative to trace elements. It is commonly known that coal and the resulting by-products have varied chemical composition and the composition includes numerous trace elements. Several trace elements commonly found in measurable quantities in coal combustion by-products (CCBs) are also of concern to EPA, as they might be significant in utility emissions. These trace elements include selenium, chlorine, cadmium, and lead. Another significant trace element of great environmental concern is mercury, which is not as commonly found in CCBs because of its unique chemistry and volatility. Mercury in utility emissions has been the focus of several recent EERC research projects (Miller et al., 1996; Laudal et al., 1996; Dunham et al., 1996), but there are many unanswered questions on the partitioning of mercury throughout coal combustion systems. Many of these questions remain to be answered for other trace elements as well, and there are additional questions regarding the impact of $\mathrm{SO}_{x}, \mathrm{NO}_{x}$, and particulate (often referred to as $\mathrm{RO}_{\mathrm{x}}$ ) emission control technologies on the fate of trace elements 
in the coal conversion processes. These issues are noted here because the evaluation of the fate of trace elements in utility systems should also include postproduction processing such as the demonstrated ex situ oxidation process or other oxidation options.

It is important to note that only very low concentrations of these elements are present in the solid and liquid samples, and the primary concern in evaluating the trace element partitioning was to understand process issues relative to product quality.

The process of forced oxidation of scrubber sludge is a process involving true solution chemistry; thus, in order for complete oxidation of sulfite to sulfate to occur, each particle of calcium sulfite must dissolve and the sulfite must become oxidized to sulfate, with subsequent recrystallization of calcium sulfate as the dihydrate (gypsum). In this process, sulfuric acid is used to adjust $\mathrm{pH}$ to approximately 4.5 and residual calcium hydroxide or associated calcium carbonate will be converted to calcium sulfate through a simple chemical conversion involving acid-base reaction. This assures the high purity and high rate of conversion of all alkaline calcium compounds to calcium sulfate in the final product.

Table 1 is a summary of chemical analyses of scrubber sludge water before forced oxidation and chemical analysis of oxidized scrubber sludge and its associated liquid phase after the completed oxidation process. The analytical data given are for the pilot-scale-produced gypsum, which was dewatered and washed prior to air drying. The use of a highly efficient dewatering and washing process would likely result in the production of a material containing lower concentrations of trace elements that partitioned into the liquid phase.

\section{TABLE 1}

Chemical Analysis of Scrubber Sludge

\begin{tabular}{lcccc}
\hline Parameter & $\begin{array}{c}\text { North Dakota } \\
\text { PDWS Limits, ppm }\end{array}$ & $\begin{array}{c}\text { Liquid from } \\
\text { Unoxidized } \\
\text { Scrubber Sludge }\end{array}$ & $\begin{array}{c}\text { Liquid from Oxidized } \\
\text { Scrubber Sludge }\end{array}$ & $\begin{array}{c}\text { Oxidized } \\
\text { Scrubber Sludge }\end{array}$ \\
\hline Cadmium & 0.01 & $<0.0003 \mathrm{ppm}$ & $0.00316 \mathrm{ppm}$ & $<0.01 \mathrm{ppm}$ \\
Chloride & & & $2050 \mathrm{ppm}$ & $103 \mathrm{ppm}$ \\
Chromium & 0.05 & $0.0044 \mathrm{ppm}$ & $1.100 \mathrm{ppm}$ & $2.6 \mathrm{ppm}$ \\
Lead & 0.05 & $<0.002 \mathrm{ppm}$ & $0.018 \mathrm{ppm}$ & $<0.4 \mathrm{ppm}$ \\
Mercury & 0.002 & $0.0016 \mathrm{ppm}$ & $0.0216 \mathrm{ppm}$ & $0.20 \mathrm{ppm}$ \\
Selenium & 0.01 & $<0.008 \mathrm{ppm}$ & $0.550 \mathrm{ppm}$ & $<0.5 \mathrm{ppm}$ \\
\hline
\end{tabular}

A sample of scrubber sludge from the pilot-scale oxidation was leached using distilled deionized water at a 20:1 liquid-to-solid ratio using the ASTM D3987 shake extraction procedure. These results are shown in Table 2. 


\section{TABLE 2}

\section{Results of Leaching}

\begin{tabular}{llccc}
\hline Parameter & $\begin{array}{c}\text { North Dakota } \\
\text { PDWS Limits, ppm }\end{array}$ & $\begin{array}{c}\text { Leaching of } \\
\text { Oxidized Scrubber } \\
\text { Sludge, ppm }\end{array}$ & $\begin{array}{c}\text { Calculated } \\
\text { Maximum } \\
\text { Concentration, }{ }^{1} \text { ppm }\end{array}$ & Actually Leached, \% \\
\hline Cadmium & 0.01 & $<0.01$ & $<0.0005$ & $\mathrm{NA}^{2}$ \\
Chromium & 0.05 & $<0.05$ & 0.130 & $<38$ \\
Lead & 0.05 & $<0.002$ & $<0.020$ & $\mathrm{NA}$ \\
Mercury & 0.002 & 0.0015 & 0.010 & 15 \\
Selenium & 0.01 (ND) & $<0.002$ & $<0.025$ & NA \\
\hline
\end{tabular}

' Calculated on the basis of bulk chernical analysis and a 20:1 liquid-to-solid ratio used for the leaching procedure.

${ }^{2}$ NA (not applicable) because of the unavailability of analytical data at or above analytical detection limits or lower levels of quantitation.

It can be seen from the results in Table 1 that trace element concentrations in liquid from oxidized scrubber sludge increase significantly from those observed in unoxidized scrubber sludge. There are likely several reasons for this observation, including the release of trace elements present in the solid matrix of the initial material as a result of the recrystallization that occurs during the conversion of calcium sulfite to calcium sulfate. The process of oxidation of scrubber sludge (calcium sulfite) requires that the calcium sulfite first dissolve, since the oxidation reaction occurs in solution, followed by oxidation to sulfate with formation of calcium sulfate crystals. The process is in a sense analogous to the recrystallization method commonly used for the purification of chemical compounds. Recrystallization results in the formation of crystals of a pure chemical compound with trace constituents excluded from the crystal matrix and thus concentrated in the solution from which the crystals formed. Additionally, the reduced $\mathrm{pH}$ of the oxidized system, which is a nominal 4.5 as compared to approximately 7.5 for unoxidized scrubber sludge as received from the power plant, would result in the solubilization of heavy metals such as cadmium and lead. These form insoluble carbonates at near neutral $\mathrm{pH}$ values and control solution concentrations in aqueous systems. It can be seen in the data from chemical analysis that favorable partitioning of nearly all associated trace elements into the liquid phase of the reaction mixture did occur. The notable exception to this is mercury. Mercury, which can also form insoluble carbonates, would be kept in solution by the formation of a chloride complex that is highly stable as well as soluble. This particular chemical system has sufficient chloride for the formation of a mercuric chloride complex; however, the verification of this by direct measurement was beyond the scope of the project. The high stability of the $\mathrm{HgCl}_{4}{ }^{2-}$ complex $\mathrm{Hg}^{2+}+4 \mathrm{Cl}^{-}=\mathrm{HgCl}_{4}{ }^{2-}, \log \mathrm{K}^{0}$ 14.47 (Lindsay, 1979) along with the high chloride-to-mercury ratio in the chemical system represented precludes most other forms of oxidized mercury; however, the possibility remains that some elemental mercury may also bs: present. 
This project focused on the use of gypsum produced from scrubber sludge for use in wallboard and for agricultural use, primarily for the remediation of sodic soils, otherwise unsuitable for crops. The primary concern for gypsum wallboard was purity of the primary product and major parameters, while for agricultural uses, trace elements were a primary concern. This study has brought out several important points. First, during the oxidation of this particular scrubber sludge, many of the trace elements partition to the liquid phase because of recrystallization purification as well as lowering of solution $\mathrm{pH}$. Second, of the trace elements remaining in the oxidized scrubber sludge, only a small percentage is leachable. Thus the minimal concentrations remaining are for the most part immobile under water leaching. The implications of included trace elements for agricultural application are not clearly defined at this time, as standards have not been established. It should be kept in mind however, that many trace elements, excluding a limited suite of heavy metals such as lead, cadmium, and mercury are either known to be essential nutrients or have been implicated in essential metabolic pathways. These include boron, chromium, and selenium, trace elements known to accumulate in CCBs and often thought of as potentially toxic trace elements rather than as nutrients. The evaluation of the potential impact of these and other trace elements must be put into the context of area of application and ambient local concentrations as well as release potential and leachability before a determination of category (hazardous or nutrient) can be made. There are numerous areas of the country where there is a deficiency of these and other essential trace elements, and their presence in an additive such as gypsum could be considered beneficial. A much more important aspect of the application of agricultural gypsum is magnesium depletion, which is known to occur with gypsum application.

\section{Wallboard Application}

Gypsum wallboard or sheetrock is a standard building material that traditionally used mined gypsum; however, in recent years, wallboard manufacturers have begun to work with utilities to use FGD gypsum. Wallboard manufacturers have specific requirements on quality and consistency as noted in Table 3 . There are some modifications required by conventional wallboard manufacturing processes to accommodate FGD gypsum and recycled gypsum, but many companies are making these adjustments. The U.S. annual consumption of gypsum is approximately 26 million tons. It is interesting to note that the production of FGD materials will be about that same amount after the Clean Air Act Amendments are fully implemented in the year 2000. It is also important to note that the use of FGD gypsum can favorably impact air quality because of the potential associated reduction in mining requirements.

\section{Agricultural Uses}

Agricultural uses of FGD gypsum and products produced from gypsum and other CCBs are numerous, and there is much literature available on this topic (Electric Power Research Institute, 1995; Forster, 1994; Hatch, 1993; Hemmings, 1995; Ohio State University, 1993; Warren, 1992). Gypsum from oxidized scrubber sludge has a number of standard agricultural uses (Clarke, 1993). These are as follows:

- Conditioning alkaline and saline, or sodic, soils

- Improving soil permeability 
- Supplying nutritional sulfur

- Providing catalytic support to maximize fertilizer absorption

- Enhancing the production of root nodules that promote the conversion of nitrogen to nitrogen compounds (Steffan, and Golden, 1991)

\section{TABLE 3}

Specifications for Gypsum Wallboard Use (Mayer, 1993)

\begin{tabular}{|c|c|c|}
\hline Property & $\begin{array}{c}\text { Composition Allowed } \\
\text { (Westroc Industries Ltd.) }\end{array}$ & $\begin{array}{c}\text { Composition in Coal Creek } \\
\text { Gypsum }\end{array}$ \\
\hline $\mathrm{CaSO}_{4} \cdot 2 \mathrm{H}_{2} \mathrm{O}$ & $95.0 \% \min$ & $98 \%-99 \%$ \\
\hline $\mathrm{CaSO}_{3}$ & $0.5 \% \max$ & $<0.1 \%(.015 \%)$ \\
\hline Free Moisture & $10.0 \% \max$ & $<1 \%$ \\
\hline Fly Ash & $1.0 \% \max$ & \\
\hline $\mathrm{SiO}_{2}$ & $1.0 \% \max$ & \\
\hline Acid Insoluble & & $0.027 \%\left(\right.$ fly ash $\left.+\mathrm{SiO}_{2}\right)$ \\
\hline $\mathrm{Ca} / \mathrm{MgCO}_{3}$ & $5.0 \% \max$ & \\
\hline $\mathrm{Fe}_{2} \mathrm{O}_{3}$ & $0.4 \% \max$. & \\
\hline $\mathrm{Cl}^{-}$ & 100 ppm max. & $103 \mathrm{ppm}$ \\
\hline $\mathrm{Na}$ & 100 ppm max. & $280 \mathrm{ppm}$ \\
\hline $\mathrm{Mg}$ & 75 ppm max. & $52 \mathrm{ppm}$ \\
\hline $\mathrm{K}$ & 100 ppm max. & $38 \mathrm{ppm}$ \\
\hline Total Soluble Salts & 600 ppm max. & \\
\hline $\mathrm{pH}$ & $6-8$ & 6.5 \\
\hline Particle Size & $20 \% \max .<10 \mu \mathrm{m}$ & $27 \%<9.6 \mu \mathrm{m}$ \\
\hline Aspect Ratio & $10 \max$ & \\
\hline
\end{tabular}

FGD residues may contain sulfite, which can be toxic to plants. There are several strategies that may be effective for overcoming, the potential phytotoxicity of sulfite in unoxidized or incompletely oxidized scrubber sludge. Raising soil $\mathrm{pH}$ can effectively accelerate the oxidation of sulfite by forming the more soluble bisulfite, which is then air-oxidized to sulfate; alternately, simply allowing sufficient time for oxidation to occur or limiting application rates, depending on sulfite content can also be done. It has been reported that oxidation need not be complete, with $50 \%-70 \%$ being acceptable (Clarke, 1993). This was not a real consideration in this study, since nearly complete oxidation of sulfite ( $>99 \%$ ) could be easily accomplished. The application rates for FGD are also highly variable; however, an application rate of 7-7 tha has been recommended in a recent report prepared in Europe (Coal Research Establishment, 1992). 
Application of gypsum to soil can also result in magnesium deficiency. Magnesium is relatively easy to displace from ion-exchange sites on soil surfaces. In the presence of the high concentrations of calcium encountered with the application of gypsum, magnesium is displaced into the soil solution. In solution, it forms a noncharged ion pair with sulfate, which can be easily leached out of the soil system (Ritchey et al., 1995). When gypsum is used in agricultural applications, magnesium deficiency should be considered and, if needed, magnesium supplement should be used. Additionally, with agricultural use, the accumulation of trace elements should be factored into use, particularly if heavy or repeated applications are anticipated. Constant monitoring of gypsum, soil, and even plant tissue may be necessary with gypsum containing potentially problematic concentrations of trace elements.

\section{General Uses for Gypsum}

Tables 4 and 5 are a summary of production and use as well as major uses for FGD. These tables are based on the American Coal Ash Association (ACAA) 1993 survey results. It can be seen from Table 5 that the three top uses for FGD account for $98 \%$ of FGD use in the United States.

\section{TABLE 4}

Summary of CCB Production and Use in the United States (Blackstock and Tyson, 1995)*

\begin{tabular}{lcccc}
\hline & FGD Products & Fly Ash & Bottom Ash & Boiler Slag \\
\hline Production* & 20.3 & 47.8 & 14.2 & 6.2 \\
Use* & 1.1 & 10.5 & 4.2 & 3.4 \\
Percent Use & $6 \%$ & $22 \%$ & $30 \%$ & $55 \%$ \\
\hline
\end{tabular}

*Millions of short tons.

TABLE 5

Summary of FGD Use in the United States (Blackstock and Tyson, 1995)

\begin{tabular}{lrr} 
FGD Uses & Tons Used* & Percent \\
\hline Wallboard & 633,526 & 54.5 \\
Waste Stabilization & 299,262 & 25.7 \\
Road Base/Subbase & 206,699 & 17.8 \\
Structural Fills, Embankments & 11,698 & 1.0 \\
Miscellaneous & 11,891 & 1.0 \\
Total & $1,163,076$ & 100.0 \\
\hline
\end{tabular}

*Figures are in short tons. 
Other potential uses include the following:

- Manufacture of ammonium sulfate fertilizer

- Cement production (cement slinker)

- Fabrication of unfired brick, cinder block, and masonry

- Industrial plasters

- Dental plaster and medical plaster

- Self-leveling floor mortar

- Oil well cements

- Waste stabilization

- Mining mortar

Since there are an extremely large number of uses for gypsum, either as gypsum $\left(\mathrm{CaSO}_{4} \cdot 2 \mathrm{H}_{2} \mathrm{O}\right)$, plaster of paris $\left(\mathrm{CaSO}_{4} \cdot 1 / 2 \mathrm{H}_{2} \mathrm{O}\right)$, or chemical calcium sulfate, this list of uses in not intended to be taken as all-inclusive. Major and inncvative applications have been selected for presentation in this summary of use potential.

\section{FULL-SCALE GYPSUM PRODUC'TION}

Based on the successful demonstration of pilot-scale gypsum production, Cooperative Power initiated an evaluation of equipment needs and costs to scale up the ex situ oxidation process at the Coal Creek Station site. Requirement; for the full-scale process were: 1) minimum disruption to current desulfurization process and 2) minimum cost for installation. Cooperative Power's plans included construction in 1998 and changes to the scrubbing material to improve $\mathrm{SO}_{2}$ removal. The equipment requirements and costs and cost of construction is detailed in a bid supplied by Dravo Lime Company and included in Appendix C.

The primary equipment required for the full-scale ex situ oxidation process is an oxidation tower, hydroclones, and belt dryers. Cooperative Power anticipates costs of $\$ 1.5 \mathrm{M}$ per unit for equipment and construction. The expected products will be gypsum and magnesium hydroxide.

\section{CONCLUSIONS AND RECOMMENDATIONS}

The following conclusions were drawn from the results of the laboratory- and pilot-scale experiments performed for this study.

- The production of high-quality gypsum suitable for agricultural use and production of wallboard, was demonstrated using Coal Creek Station scrubber sludge. The scrubber sludge was relatively easy to oxidize using simple techniques that could be easily automated, so commercial-scale production has a high potential for success.

- Potentially problematic trace elements, including heavy metals and chloride, appear to partition into the liquid phase during the oxidation process, likely because of recrystallization purification. of the product as well as $\mathrm{pH}$ adjustment to 4.5 necessary for air oxidation. 
- Concentrations of many of the potentially problematic trace elements are not especially high and thus not of concern for normal agricultural application rates. Trace element concentrations are for the most part not a concern in wallboard application prior to disposal, which is inevitable. Recent recommendations for agricultural application of disposed wallboard may impose trace element considerations for this application.

- Potentially toxic trace elements remaining in the oxidized scrubber sludge at measurable or potentially problematic levels exhibited limited mobility either at or below the concentrations for primary drinking water standard limits.

- Dewatering of the oxidized scrubber sludge was readily accomplished. The degree of dewatering that can be accomplished will affect concentrations of trace elements in the produced gypsum that are inversely proportional to the efficiency of dewatering. This is due to the partitioning of the trace elements into the liquid phase during the oxidation process.

- There is a relatively high volume of literature available on FGD, gypsum, and related topics. Especially useful are proceedings from the international conferences on FGD and other synthetic gypsum sponsored by Ortech and held every other year in Toronto. A bibliography of selected publications including these proceedings is presented in Appendix B.

The potential markets for agricultural and wallboard-grade gypsum are numerous and as yet untapped in many areas of the country. The primary consideration, especially in the upper Midwest, other than purity and presence of potentially problematic trace constituents, is the problem of transportation of gypsum from generally remote power plants to accessible markets. Using gypsum produced from scrubber sludge for agricultural applications is an easy way to overcome this particular problem, since remotely located power plants are often very near the agricultural markets.

Wallboard applications may necessitate the manufacture of wallboard near the source of the scrubber sludge, providing a higher-value product for transport to both local and remote markets. This requires a reliable, high-volume, and consistent quality source of scrubber sludge for gypsum production.

The EERC makes the following recommendations:

- Ex situ air oxidation is recommended for production of high-purity gypsum at the CCS site based on the laboratory- and pilot-scale demonstrations performed in this study. Many trace elements, especially heavy metals, favorably partitioned into the liquid phase during ex situ air oxidation, resulting in an especially pure form of gypsum. In situ forced oxidation systems would allow trace constituents to be included in the product.

- Past history with ash and analysis of air toxic trace elements at Coal Creek Station would indicate that trace elements are not currently a problem, however quality of any marketed product should be monitored on a regular basis. This is especially important if fuel sources change significantly. 
- Trapping of additional $\mathrm{SO}_{2}$ to lower the initial $\mathrm{pH}$ of Coal Creek Station scrubber sludge could be used as a means to reduce sulfuric acid needed for $\mathrm{pH}$ control in the air oxidation process.

- Standards for agricultural gypsum trace element concentrations should be established based on total concentrations as well as plant availability and leaching potential. For scrubber sludge containing potentially problematic concentrations of trace elements, application limits and maxirnum soil concentrations would need to be established. Since different plant species accurnulate and transport trace elements differently, this is an especially complex undertaking. Since accumulation of potentially toxic trace elements is a concern, not only with oxidized scrubber sludge but also with gypsum from natural sources, application should be based on need rather than a blanket amount. Additionally, as with the application of ary foreign material on soil on which food will be grown, the accumulation of potentially harmful trace elements must always be kept in mind, especially if repeated application is anticipated or necessary. As was stated in the text of the report, magnesium depletion can be experienced with gypsum application to soils. This may require the addition of magnesium supplements.

\section{REFERENCES}

Blackstock, T.H.; Tyson, S.S. "Coal Combustion By-Products (CCB's): Overview of Applications and Opportunities in the U.S.A.," In Proceedings of the 4th International Conference on FGD and Other Synthetic Gypsum, May 17-18, 1995 Toronto, Canada; pp 24-1 to 24-4.

Clarke, L.B. Management of Residues from Flue Gas Desulphurisation Systems; IEA Coal Research: Gemini House 10-18 Putney Hill, London SW15 6AA; April 1993.

Coal Research Establishment (CRE). (1992) " Disposal and Utilization of Flue Gas Desulfurization (FGD) Residues." EUR report EUR-14071-EN; Commission of the European Communities, Luxembourg.

Dunham, G.E.; Miller, S.J.; Chang., R.; Bergman, P.D. "Investigation of Mercury Control in Baghouses with Sorbents," Presented at the 1996 Air \& Waste Management Association 89th Annual Meeting \& Exhibition. Nashville, TN, June 23-28, 1996.

Karlson, H.T.; Bengtson, S.; Bjeerle, I.; Klingspor, J.; Nilsson, L-I.; Stromberg, A-M. "Oxidation of Sulfite to Sulfate in Flue Gas Desulfurization Systems," In Processing and Utilization of High Sulfur Coals; Attia, Y.A., Ed.; Elsevier: Amsterdam, 1985, 589 p. (Also Vol. 9 of the series Coal Science and Technology, Proceedings of the 1st International Conference on Processing and Utilization of High Sulfur Coals, Oct. 13-17, 1985, Columbus Ohio.)

Laudal, D.L.; Heidt, M.K.; Brown, T.D.; Nott, B.R.; Prestbo, E.P. "Mercury Speciation: A Comparison Between EPA Method 29 and Other Sampling Methods, " Presented at the 1996 Air \& Waste Management Association 89th Annual Meeting \& Exhibition, Nashville, TN, June 23-28, 1996. 
Lindsay W.L. Chemical Equilibrium in Soils; Wiley-Interscience, 1979; ISBN 0-471-02704-9, p. 346.

Mayer, P.J. "Physical Factors Which Affect Desulphogypsum Utilization," In Proceedings of the 3rd International Conference on FGD Gypsum and Other Synthetic Gypsum, Sept. 26-28, 1993, Toronto, Canada; pp 19-1 to 19-16.

Miller, S.J.; Ness, S.R.; Weber, G.F.; Erickson, T.A.; Hassett, D.J.; Hawthorne, S.B.; Katrinak, K.A.; Louie, P.K.K. "A Comprehensive Assessment of Toxic Emissions from Coal-Fired Power Plants: Phase I Results from the U.S. Department of Energy Study," EERC final report for DOE Contract No. DE-FC21-93MC30097 Subtask 2.3.3.; Sept. 1996.

Ritchey, K.D.; Feldhake, C.M.; et al., "Use of FGD Gypsum in Management of Acid Soils," In Proceedings of the 4th International Conference on FGD Gypsum and Other Synthetic Gypsum, May 17-18, 1995, Toronto, Canada; pp 20-1 to 20-16.

Steffan, P.; Golden, D. "FGD Gypsum Utilization-Survey of Current Practices and Assessment of Market Potential; In Proceedings of the 2nd International Conference on FGD and Chemical Gypsum, Toronto Canada, May 12-15, 1991; Ortech International Corporation. 
APPENDIX A

\section{DESCRIPTION OF THE PILOT-SCALE DEMONSTRATION}




\section{DESCRIPTION OF THE PILOT-SCALE DEMONSTRATION}

\section{INTRODUCTION}

Following bench-scale testing for proof of concept and basic process development, it was desirable to increase the scale of testing to determine the scalability of process parameters, the quality of the final product, and the potential for granulation/pelletization of the oxidized product. A pilot-scale oxidation process was assembled and operated to convert raw Coal Creek Station scrubber sludge to synthetic gypsum. The synthetic gypsum was subsequently washed, dewatered, and floor-dried prior to final analyses and pelletization/granulation testing.

\section{EQUIPMENT}

The pilot-scale oxidation testing, was conducted in a 54-in.-diameter, insulated, stainless-steel tank with a 49-in. sidewall depth and a shallow, conical bottom. The nominal capacity of this tank was $500 \mathrm{gal}$. A 2-in. stainless-steel pipe was connected to the bottom of the tank cone and served as a drain. A single pneumatic mixer with a two-paddle impeller attached to a 55-in.-long shaft was used to maintain complete-mix conditions in the tank and to keep the sludge solids in suspension. Each impeller paddle had a surface area of approximately $0.188 \mathrm{ft}^{2}$. The $\mathrm{pH}$ of the tank contents was monitored via a Beckman Model 960B pH monitor/controller. Dilute sulfuric acid solution $\left(20 \% \mathrm{H}_{2} \mathrm{SO}_{4}\left[66^{\circ} \mathrm{Be}\right.\right.$, technical grade] in deionized water) was added at a rate of approximately $0.1 \mathrm{gal} / \mathrm{min}$ with a peristaltic pump when called for by the $\mathrm{pH}$ controller. Compressed air from the Energy \& Environmental Research Center (EERC) house air system (maintained at approximately $90 \mathrm{psig}$ ), in the form of fine bubbles, was supplied to the suspension through two 2-ft-long by $21 / 2$-in.-diameter flexible membrane tube diffusers produced under the trade name Sanitare by the Water Pollution Control Corporation, Milwaukee, Wisconsin. Airflow to each diffuser was measured through rotameters scaled from 40 to $400 \mathrm{scfh}$. The bulk scrubber solution was transferred from 55-gal barrels to the reaction tank and subsequently back to the barrels via an airdriven diaphragm pump containing 12-in.-diameter diaphragms. Offgases from the oxidizing suspension were pulled from the reaction tank headspace via a $7.5 \mathrm{hp}$ Sutorbilt induced-draft blower through a coarse-bubble diffuser in approximately 45 gal $(170 \mathrm{~L})$ of a $\mathrm{NaHCO}_{3}$ scrubber solution and exhausted outside of the building. The blower was operated to pull a vacuum of approximately 24 in. of water.

\section{PROCEDURES}

Upon completion of pilot-scale equipment assembly, each of the 55-gal drums of scrubber sludge was placed into a barrel turner: and rotated for up to $60 \mathrm{~min}$ to completely suspend any solids that had settled during shipment. When it was assured that all solids were resuspended, the contents of each barrel were immediately transferred to the reaction tank, where the raw scrubber sludge solids were maintained in suspension via the pneumatic mixer. When all eight barrels of scrubber sludge had been resuspended and transferred to the reaction tank, a sample of the raw scrubber sludge was taken to determine baseline oxidation conditions; the $\mathrm{pH}$ of the suspension was reduced to about 4.6 with $20 \% \mathrm{H}_{2} \mathrm{SO}_{4}$ solution; and compressed air was turned on to the diffusers to start 
the oxidation process. Samples of the suspension were taken periodically to determine the percent conversion of sulfite to sulfate. With the exception of the first night of the run, the oxidation procedure was continuous. A portable gas analyzer was used to measure the quality of the offgases in the reaction tank headspace in terms of $\mathrm{O}_{2}, \mathrm{CO}_{2}, \mathrm{SO}_{2}$, and temperature. The offgases were drawn through a scrubbing solution composed of $1.87 \mathrm{lb}(0.85 \mathrm{~kg})$ of $\mathrm{NaHCO}_{3}$ dissolved in approximately 45 gal $(170 \mathrm{~L})$ of tap water. When it was determined that the oxidation reactions had gone to completion, i.e., the majority of suspended solids had been converted to $\mathrm{CaSO}_{4} \cdot 2 \mathrm{H}_{2} \mathrm{O}$; airflow to the diffusers was shut off and the oxidized suspension was transferred back to 55-gal drums for settling and decanting.

The oxidized solids were allowed to settle, and the supernatant wastewater was decanted from each barrel and pumped back to the 500-gal reaction tank. The settled solids were then triplewashed with deionized water to remove the majority of included contaminants. After each washing operation, the oxidized product was allowed to settle and the supernatant was decanted and combined with the initial wastewater volume. The final volume of wastewater, approximately $315 \mathrm{gal}$ (1192 L), was neutralized with $\mathrm{NaOH}$ and discharged to the municipal sanitary sewer system.

Following the solids-washing operations, the wet solids were dewatered via vacuum filtration and transferred to $6-\mathrm{ft}^{3}$ totes for ease of transport. The dewatered solids were subsequently weighed and placed into windrows for floor drying. Electric fans were used to maintain air circulation over the windrows to promote drying of the synthetic gypsum product. When the product was dry to the touch and no longer wetted the concrete beneath the windrows, the material was recovered and placed into lined polyethylene 55-gal drums for storage. The floor-dried synthetic gypsum product was subsequently shipped to MMC Mars Mineral, Mars, Pennsylvania, for pelletizing tests. A small amount of the product was initially used to determine the unit operations and binding agent appropriate to produce satisfactory pellets. The remainder of the bulk sample was then processed into pellets and returned to the EERC.

\section{RESULTS AND DISCUSSION}

The eight drums of raw scrubber sludge received from Coal Creek Station contained a total net weight of about $4040 \mathrm{lb}(1834 \mathrm{~kg})$, with an initial solids content of $10 \%-12 \%$ and a bulk density of $69.5 \mathrm{lb} / \mathrm{ft}^{3}(1.12 \mathrm{~kg} / \mathrm{L})$. After the material was resuspended and transferred from the drums to the reaction vessel, the $\mathrm{pH}$ of the suspension was adjusted down from the initial level of 7.7 to about $4.7 \mathrm{using} 44 \mathrm{lb}(20 \mathrm{~kg})$ of $20 \% \mathrm{H}_{2} \mathrm{SO}_{4}$ solution. The scrubber sludge was oxidized over a period of $80 \mathrm{hr}$, at which point nearly $98 \%$ of the calcium sulfite solids in the raw sludge suspension had been converted to gypsum. Figure 1 is a graph of percent conversion of scrubber sludge versus time. Two additional lines are shown on this chart. These represent linear regression lines plotted against select data. It was observed that the rate of oxidation during the first day was considerably faster than for the remainder of the run. Line 1 is a line thorough the origin and the first Data point recorded at $1 \mathrm{hr}$, at which time $5.47 \%$ of the sulfite had been converted to sulfate. Line 2 includes a data point at $4 \mathrm{hr}$, at which time $9.58 \%$ of the sulfite had been oxidized. These regression lines do not include sufficient data to be accurate; however, they can be used to demonstrate that it may have been possible to achieve complete conversion in a much shorter time than was experienced. It is interesting to note that the titration conducted on the first two grab 


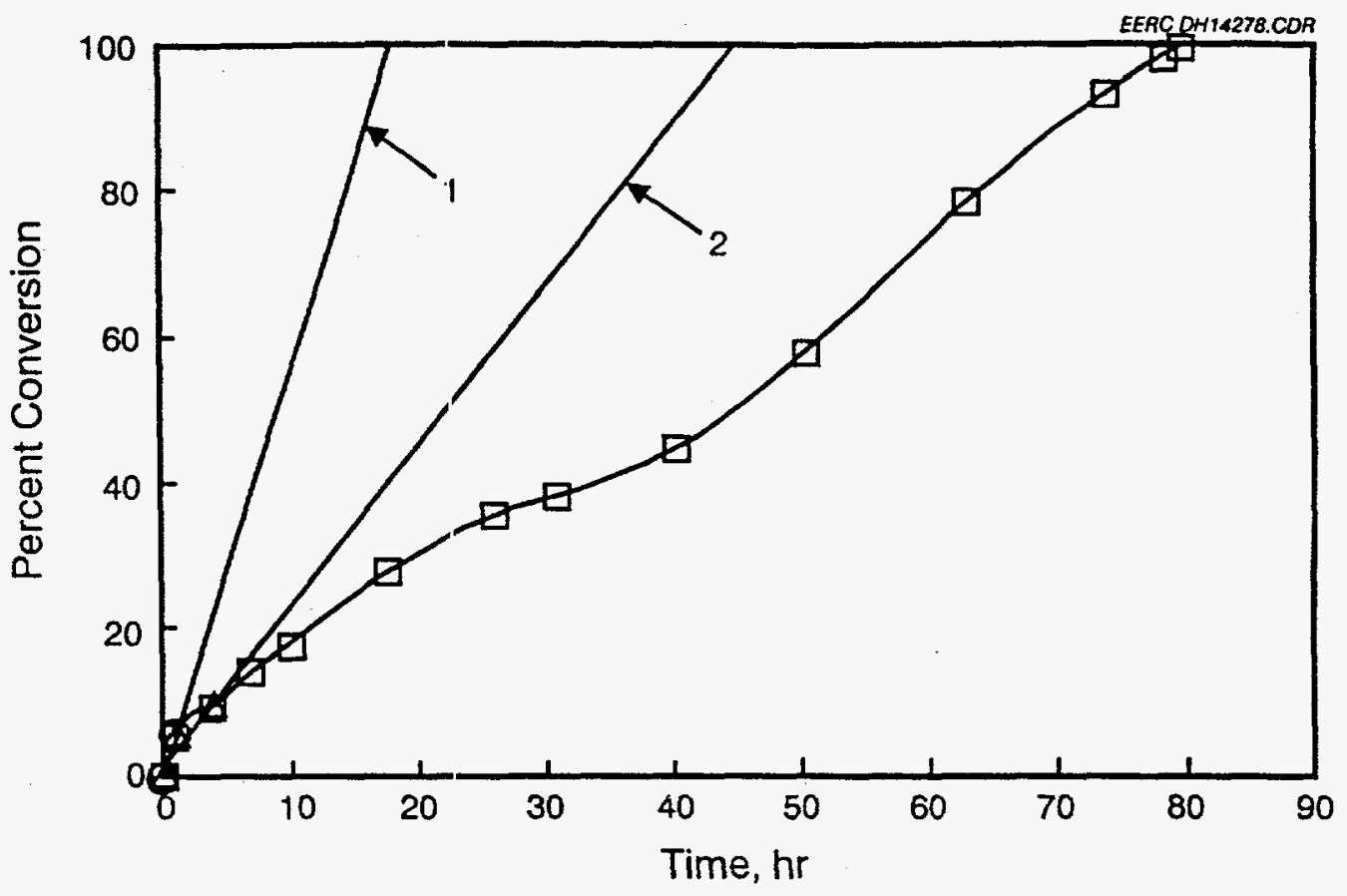

Figure 1. Percent conversion versus time for the pilot plant oxidation of North Dakota Scrubber Sludge

samples taken, one from each of the first $2 \mathrm{hr}$ of operation, indicated that the reaction was proceeding at between $2.4 \%$ and $4.5 \% / \mathrm{hr}$. At this range of oxidation, it was estimated that the suspended solids would be completely oxidized in from 20 to $40 \mathrm{hr}$. However, aeration to the suspension was discontinued for $15.5 \mathrm{hr}$, from $1715 \mathrm{hr}$ on Day 1 of the test, to $0845 \mathrm{hr}$ on Day 2, so that close inspection of the oxidation procedure could be maintained. Following resumption of aeration on Day 2, the instantaneous oxidation rate never climbed above $1.6 \% / \mathrm{hr}$. The reason for this decline in oxidation rate is unclear. It is possible that the suspended scrubber solids underwent some type of chemical alteration during the $15.5 \mathrm{hr}$ period of nonaeration due to the sulfuric acid added to reduce the $\mathrm{pH}$ of the suspension. In laboratory experiments, it was observed that a $\tan$, very finely divided material tended to form with time. This material has not been characterized, but may have coated scrubber sludge particles or in other ways interfered with the oxidation process.

To increase the rate of oxidation, the $\mathrm{pH}$ of the suspension was reduced to between 4.5 and 4.7 by adding $20 \%$ sulfuric acid. As the reaction proceeded, some of the acid in solution was consumed and the $\mathrm{pH}$ increased slow/ly. To maintain the solution $\mathrm{pH}$ in the proper range, additional acid was added as needed via a peristaltic pump connected to a $\mathrm{pH}$ monitor/controller. A total of $132.5 \mathrm{lb}(60.2 \mathrm{~kg})$ of the dilute acid was used throughout the course of the oxidation test to maintain the desired $\mathrm{pH}$. This reduces to about $3 \mathrm{gal}(11.4 \mathrm{~L})$ of concentrated sulfuric acid used to oxidize the approximately $435 \mathrm{gal}(1646.5 \mathrm{~L})$ of raw scrubber sludge. The sulfuric acid consumption resulted in the release of $\mathrm{SO}_{2}$ into the headspace of the enclosed reaction tank. The concentration of $\mathrm{SO}_{2}$ in the reaction tank headspace averaged $152 \mathrm{ppm}$ for the period of the test prior to complete oxidation. For this same period of time, the maximum concentration of $\mathrm{SO}_{2}$ was $332 \mathrm{ppm}$, while the minimum was $7.5 \mathrm{ppm}$. At the point at which the scrubber sludge solids were completely oxidized, the $\mathrm{pH}$ of the suspension dropped from the normal operating level of 
approximately 4.6 to near 3.0. This corresponded to a dramatic increase in $\mathrm{SO}_{2}$ emissions, as the concentration of $\mathrm{SO}_{2}$ in the reactor headspace increased to over $1200 \mathrm{ppm}$.

At the conclusion of the oxidation test procedure, the suspension was transferred to eight 55-gal open-top barrels to settle the oxidized solids and decant the supernate back to the reaction tank for final treatment and disposal. The moist settled solids were washed with deionized water at a ratio of about 0.25 gal of water per gal of moist solids three separate times to remove the majority of contaminants present among the gypsum crystals. The moist solids were then dewatered to an average moisture content of $28.5 \%$ via vacuum filtration at about $27 \mathrm{in}$. of $\mathrm{Hg}$. The dewatered solids were floor-dried in two batches, the first batch for approximately $48 \mathrm{hr}$, and the second batch for over $120 \mathrm{hr}$, with similar results for both, i.e.; each batch lost the same percentage of moisture. The final moisture content of the material following floor drying indicated that the material was calcium sulfate hemihydrate with a nominal water content of $20 \mathrm{wt} \%$. The total amount of synthetic gypsum produced and collected was $675 \mathrm{lb}(306 \mathrm{~kg})$, with an approximate bulk density of $47 \mathrm{lb} / \mathrm{ft}^{3}$ $\left(753 \mathrm{~kg} / \mathrm{m}^{3}\right)$.

The supernate decanted from the oxidized and settled scrubber solids, along with the water used to wash the moist solids, represents a wastewater that required treatment prior to disposal. The 315 gal (1192 L) of collected wastewater was acidic and therefore was neutralized with $\mathrm{NaOH}$ at a rate of about $0.0078 \mathrm{lb} / \mathrm{gal}(0.935 \mathrm{~g} / \mathrm{L})$ to a $\mathrm{pH}$ of 7.0 . The $\mathrm{NaOH}$ addition resulted in the formation of a lightweight yellow precipitate. Following neutralization, the wastewater was analyzed for chemical oxygen demand (COD), which measured $863 \mathrm{mg} / \mathrm{L}$, filtered, and discharged to the municipal sanitary sewer. The use of COD must be approached with caution, since the presence of any unreacted sulfite as $\mathrm{SO}_{2}$ could appear as COD. It is likely that the actual COD of this solution (minus the sulfite present) was considerably lower than the test results indicated. The precipitate that was filtered from the neutralized wastewater totaled about $80 \mathrm{lb}(36 \mathrm{~kg})$ at a moisture content of about $30 \%$. The offgas scrubber solution had a final pH of 7.5 and a COD of $30 \mathrm{mg} / \mathrm{L}$ and was discharged without additional treatment.

The majority of the floor-dried gypsum product was shipped to MMC Mars Mineral for pelletization testing. MMC Mars Mineral performed three preliminary bench-scale tests on a small portion of the total sample to define the optimum processing operations to produce a quality pelletized product within the size range requested $(6 \times 20$ mesh).

The first preliminary test was run using the synthetic gypsum and $3 \%$ plaster of paris $\left(\mathrm{CaSO}_{4} \cdot 1 / 2 \mathrm{H}_{2} \mathrm{O}\right)$ by weight as the binding agent. The gypsum and binder were fed into a pin mixer with moisture addition, but at all operational settings attempted, satisfactory pelletization could not be achieved. This test produced a granular type of pellet (similar to a grain of salt), with only $20 \%$ of the final product in the required $6 \times 20$-mesh size range, $46.6 \%$ between 20 and 80 mesh, and the remaining $33.4 \%$ smaller than 80 mesh.

The second test was performed using the synthetic gypsum and a lignosulfonate (Norlig-H) as the binding agent. The Norlig- $\mathrm{H}$ was mixed with water at a concentration of $50 \%$ by weight and introduced into the pin mixer through spray nozzles. This test was more successful in producing a larger pellet with less overall fines. The particle-size distribution for the final product of the second test was as follows: $51.1 \%$ of the pellets fell in the $6 \times 20$-mesh size range; $33.5 \%$ were less than 20 mesh, of which $4.6 \%$ was less than 80 mesh and considered powder; and $15.4 \%$ were larger 
than 6 mesh. Some of the larger pellets were due to lumps in the as-received raw material (synthetic gypsum).

The third test was essentially a repeat of the second test, except that the product from the pin mixer was then run through a disc pelletizer as a finishing step. In this application, the pin mixer was used to partially pelletize and condition the material. The conditioned material was passed through a 6-mesh screen to remove lumps that were not broken up in the pin mixer. This screened material was then run through the disc pelletizer with small amounts of binder added at the disc to complete the pelletization and help control final pellet sizing. With this series of operations, it was possible to produce $90.2 \%$ on-spec pellets, with only $0.7 \%$ smaller than 20 mesh.

Tests in addition to the sieve analyses mentioned above were performed on the raw material fed to the pelletization process as well as on the pelletized products. The results of these tests are shown in Tables A-1 through A-3. Since the plaster of paris binding agent was added directly to the synthetic gypsum prior to feeding to the pin mixer, a separate raw material analysis was performed for Test 1 , as shown in Table A-1. The raw material was equivalent for Tests 2 and 3, and therefore only one raw material analysis was performed and is shown for these tests.

The remainder of the bulk sample sent to MMC Mars Mineral and not utilized for benchscale testing was pelletized in an extended run using the same process used in Test 3 discussed above. As during Test 2, 50\% Norlig- $\mathrm{H}$ lignosulfonate and water by weight was used as the binding agent. The bulk density of the Norlig- $\mathrm{H}$ and water mixture was $70.3 \mathrm{lb} / \mathrm{ff}^{3}(1.13 \mathrm{~kg} / \mathrm{L})$.

The synthetic gypsum was fed by hand into a 3 -in. $(7.6-\mathrm{cm})$ open-flight, volumetric feeder. The volumetric feeder delivered the material to a 12D54L pin mixer/pelletizer at a feed rate of $1080 \mathrm{lb} / \mathrm{hr}(490 \mathrm{~kg} / \mathrm{hr})$. The pin mixer was equipped with a 40-hp drive motor, with a variablespeed sheave and adjustable motor base. The rotor speed was set at $900 \mathrm{mpm}$, with motor current recorded at 24 amps. The moisture-binder mixture was injected into the pin mixer near the inlet side through a No. 4003 Spraying Systems spray nozzle at 26 psi. This is equivalent to a flow rate of $0.24 \mathrm{gpm}(0.91 \mathrm{Lpm})$. The conditioned material exited the pin mixer at a moisture content of $25.4 \%$ by weight.

Thê partially pelletized, conditioned material was fed by hand into a Model P-30 pan pelletizer. The P-30 pan pelletizer is equipped with a 1 -hp drive motor, with a variable-speed sheave and adjustable motor base. The pan is $3 \mathrm{ft}(0.91 \mathrm{~m})$ in diameter and has an 8-in. (20.3-cm) depth. The pan angle was set $36^{\circ}$ from horizontal, and the pan was rotated at $16 \mathrm{rpm}$. Binder was added through a No. 4001 Spraying Systems spray nozzle and delivered intermittently to the 4 o'clock position at $0.07-0.09 \mathrm{gpm}(0.26-0.34 \mathrm{Lpm})$. The conditioned feed material was delivered to the pan at the 3 o'clock position.

The conditioned material pelletized at a moisture content of $29.6 \%$ (by weight). Some difficulty was encountered keeping the product pellets within the target size range, which was $10 \times 30$ mesh for the extended test. The product pellets had a tendency to grow too large, with $75.7 \%$ larger than 10 mesh. Some of the product material that measured larger than 6 mesh was attributed to excessive buildup of material on the pan scrapers. The product of the extended run was then spread out on cardboard and air-dried for approximately $60 \mathrm{hr}$ prior to repackaging and shipment back to the EERC. Upon receipt of the air-dried pellets at the EERC, the pellets were oven dried at $160^{\circ} \mathrm{C}$ for approximately $3 \mathrm{hr}$ to complete the process. Tables A-4 and A-5 show the results of analyses performed on the pellets produced during the extended test. 
TABLE A-1

Pelletization Testing - Raw Material Sieve Analyses

\begin{tabular}{lcccccc}
\hline & & \multicolumn{3}{c}{ Test 1 } & \multicolumn{2}{c}{ Tests 2 and 3 } \\
\cline { 6 - 7 } \cline { 5 - 6 } Mesh, & $\begin{array}{c}\text { Opening Size, } \\
\text { U.S. Std. }\end{array}$ & $\begin{array}{c}\text { F.etained, } \\
\%\end{array}$ & $\begin{array}{c}\text { Cumulative } \\
\text { in }\end{array}$ & $\begin{array}{c}\text { Retained, } \% \\
\text { Retained, }\end{array}$ & $\begin{array}{c}\text { Cumulative } \\
\text { Retained, \% }\end{array}$ \\
\hline 10 & 0.0787 & 0.7 & 0.7 & 1.3 & 1.3 \\
45 & 0.0138 & 1.6 & 2.3 & 2.2 & 3.5 \\
80 & 0.0070 & 1.7 & 4.0 & 2.6 & 6.1 \\
120 & 0.0049 & 1.5 & 5.5 & 2.0 & 8.1 \\
200 & 0.0029 & 3.7 & 9.2 & 4.4 & 12.5 \\
325 & 0.0017 & 9.5 & 18.7 & 11.9 & 24.4 \\
Pan & 0.0000 & 81.3 & 100.0 & 75.6 & 100.0 \\
\hline
\end{tabular}

TABLE A-2

Pelletization Testing - Product Analyses

\begin{tabular}{lccc}
\hline Analysis & $\begin{array}{c}\text { Green } \\
\text { Pellets }\end{array}$ & $\begin{array}{c}\text { Air-Dried } \\
\text { Pellets }\end{array}$ & $\begin{array}{c}\text { Oven-Dried } \\
\text { Pellets }\end{array}$ \\
\hline Moisture Content, \% & & & \\
Test 1 & 29.2 & 21.5 & 12.4 \\
Test 2 & 26.1 & 20.6 & 14.3 \\
Test 3 & 30.5 & 26.1 & 16.2 \\
Bulk Density, lb/ft & & & \\
Test 1 & 43.4 & 45.4 & 53.5 \\
Test 2 & 44.5 & 50.5 & 37.5 \\
Test 3 & 58.3 & 55.7 & 47.3 \\
18-in. Drop Test, average & & & \\
Test 1 & 4.0 & 2.0 & 1.0 \\
Test 2 & 9.1 & $50+$ & $50+$ \\
Test 3 & 9.8 & 6.4 & $50+$ \\
Crush Test, lb & & & \\
Test 1 & 0.0 & 0.0 & 0.0 \\
Test 2 & 0.0 & 1.8 & 0.2 \\
Test 3 & 0.0 & 0.0 & 3.5 \\
Attrition Test, \% loss & & & \\
Tëst 1 & 50.4 & 19.8 & 51.9 \\
Test 2 & 37.3 & 2.3 & 6.0 \\
Test 3 & 0.1 & 2.1 & 1.9 \\
\hline
\end{tabular}


TABLE A-3

Pelletization Testing - Product Sieve Analyses

\begin{tabular}{|c|c|c|c|c|c|c|c|}
\hline \multirow[b]{2}{*}{$\begin{array}{l}\text { Mesh, } \\
\text { U.S. } \\
\text { Std. }\end{array}$} & \multirow[b]{2}{*}{$\begin{array}{l}\text { Opening } \\
\text { Size, } \\
\text { in. }\end{array}$} & \multicolumn{2}{|c|}{ Test 1} & \multicolumn{2}{|c|}{ Test 2} & \multicolumn{2}{|c|}{ Test 3} \\
\hline & & $\begin{array}{c}\text { Retained, } \\
\%\end{array}$ & $\begin{array}{c}\text { Cumulative } \\
\text { Retained, } \\
\% \\
\end{array}$ & $\begin{array}{c}\text { Retained, } \\
\% \\
\end{array}$ & $\begin{array}{c}\text { Cumulative } \\
\text { Retained, } \\
\%\end{array}$ & $\begin{array}{c}\text { Retained, } \\
\% \\
\end{array}$ & $\begin{array}{c}\text { Cumulative } \\
\text { Retained, } \\
\%\end{array}$ \\
\hline 6 & 0.1320 & & & 15.4 & 15.4 & 9.1 & 9.1 \\
\hline 10 & 0.0787 & 3.8 & 3.8 & 17.5 & 32.9 & 65.0 & 74.1 \\
\hline 16 & 0.0469 & 8.2 & 12.0 & 20.4 & 53.3 & 23.1 & 97.2 \\
\hline 20 & 0.0331 & 8.0 & 20.0 & 13.2 & 66.5 & 2.1 & 99.3 \\
\hline 30 & 0.0232 & 6.8 & 26.8 & 13.0 & 76.5 & 0.4 & 99.7 \\
\hline 40 & 0.0165 & 8.3 & 35.1 & 8.5 & 85.0 & & \\
\hline 60 & 0.0090 & 19.2 & 54.3 & 7.6 & 92.6 & & \\
\hline 80 & 0.0070 & 12.3 & 66.6 & 2.8 & 95.4 & & \\
\hline Pan & 0.0000 & 33.4 & 100.0 & 4.6 & 100.0 & 0.3 & 100.0 \\
\hline
\end{tabular}

TABLE A-4

Extended Pelletization Testing - Product Analyses

\begin{tabular}{lcc}
\hline Analysis & Green & Air-Dried \\
\hline Moisture Content, \% & Pellets & Pellets \\
Bulk Density, lb/f ${ }^{3}$ & 29.6 & 18.5 \\
18-in. Drop Test, average & 57.8 & 53.5 \\
Crush Test, lb & 12.0 & $50+$ \\
Attrition Test, \% loss & 0.3 & 5.6 \\
\hline
\end{tabular}

2

TABLE A-5

\section{Extended Pelletization Testing - Product Sieve Analysis}

\begin{tabular}{lccc}
\hline $\begin{array}{l}\text { Mesh, } \\
\text { U.S. Std. }\end{array}$ & $\begin{array}{c}\text { Opening Size, } \\
\text { in. }\end{array}$ & $\begin{array}{c}\text { Retained, } \\
\%\end{array}$ & $\begin{array}{c}\text { Cumulative } \\
\text { Retained, } \%\end{array}$ \\
\hline 6 & 0.1320 & 37.4 & 37.4 \\
10 & 0.0787 & 38.3 & 75.7 \\
16 & 0.0469 & 19.5 & 95.2 \\
20 & 0.0331 & 3.2 & 98.4 \\
30 & 0.0232 & 0.5 & 98.9 \\
Pan & 0.0000 & 1.1 & 100.0 \\
\hline
\end{tabular}


APPENDIX B

SELECTED BIBLIOGRAPHY 


\section{SELECTED BIBLIOGRAPHY}

The following is not intended to be an all-inclusive bibliography, but is rather a compilation of references that the authors found useful during the course of the research project.

American Society for Testing and Materials. "Physical Testing of Gypsum Board Products and Gypsum Lath," ASTM C 473-84a.

American Society for Testing and Materials. "Standard Specification for Gypsum Wallboard," ASTM C 36-84a.

Baligar, V.C.; Clark, R.B.; Kinraide, T.B.; Ritchey, K.D.; Wendell, R.R. "Strategies for Overcoming Temporary Phytotoxic Effects of Calcium Sulfite Applied to Agricultural Soils," In Proceedings of the 11th Annual International Pittsburgh Coal Conference; Pittsburgh, PA, Sept. 12-16, 1994; Chiang, S.H., Ed.; Vol. 1, pp 457-462.

Baliger, V.C.; Clark, R.B.; Ritchey, K.D. "Dry Matter Yields of Maize Grown with Coal Combustion By-Products," In Proceedings of the 10th International Ash Use Symposium; Jan. 1993.

Baligar, V.C.; Clark, R.B.; Ritchey, K.D.; Zeto, S.K. "Benefits and Concerns of High-Sulfate Flue Gas Desulfurization By-Products on Plant Growth in Acid Soil," In Proceedings of the 11th Annual International Pittsburgh Coal Conference; Pittsburgh, PA, Sept. 12-16, 1994; pp 443-449.

Baligar, V.C.; Clark, R.B.; Ritchey, K.D.; Zeto, S.K. "Grass and Legume Growth on Acid Soil Amended with FGD By-Products," In Proceedings of 1995 International Ash Utilization Symposium; Lexington, KY, Oct. 23-25, 1995; University of Kentucky Center for Applied Energy Research.

Bannwarth, H.; Schmelz, S.; Wilke, I. "Ecological Utilization Possibilities of Brown Coal Ash and Flue Gas Gypsum (FGD Gypsum)," VGB Kraftwerkstechnik 1992, 72 (7), 596-608.

Beckett, P.H.T.; Bouma, J.; Farina, M.P.W.; Fey, M.V.; Miller, W.P.; Pavan, M.A.; Shainberg, I.; Sumner, M.E.; Tiller, K.G. "Use of Gypsum on Soil: A Review," Advances in Soil Sciences 1989, 9, 2-101.

Beeghly, J.H.; Bigham, J.; Dick, W.A. "An Ohio Based Study on Land Application Uses of Dry FGD By-Products," In Proceedings of the American Coal Ash Association 10th Coal Ash Symposium; Orlando, FL, Jan. 17-23, 1993.

Bengtsson, S.; Bjerle, I.; Karlsson, H.T.; Klingspor, J.; Nilsson, L-I.; Stromberg, A.M. "Oxidation of Sulfite to Sulfate in Flue Gas Desulfurization Systems," In Proceedings of the 1st International Conference on Processing and Utilization of High Sulfur Coals; Columbus, OH, Oct. 13-17, 1985. 
Bhaskara K.; Rao, G.G. "Oxidimetric Methods for the Volumetric Estimation of Sulphite," Anal. Chim. Acta 1955, 13, 313-322.

Bigham, J.M.; Dick, W.A.; Fowler, R.; Lal, R.; McCoy, E.L.; Stenhouwer, R.C.; Sutton, P.; Traina, S.J. "Plant Growth and Soil Properties Responses to Additions of Dry Flue Gas Desulfurization By-Products," Presented at EPRI/U.S. EPA $1993 \mathrm{SO}_{2}$ Control Symposium, Boston, MA, Aug. 24-27, 1993.

Birckhead, R. "Impact of Changing State and Federal Regulations on Ash Management at Virginia Power," In Proceedings of the 1 lth International Symposium on Use and Management of Coal Combustion By-Products; Jan. 1995; Vol 2.

Bruinius, J.A.; Chou, M.-I.M.; Li, Y.C.; Lytle, J.M.; Rostam-Abadi, M. "Manufacture of Ammonium Sulfate Fertilizer from FGD Gypsum," Prepr. Pap.-Am. Chem. Soc., Div. Fuel Chem., 40 (4); 210th ACS National Meeting, Chicago, IL, Aug.; pp 896-900.

Callaway, D.; Dorsett, D.J.; Nickel, l..; Pennington, H.D. "Preliminary Evaluation of Coal Generated By-Product Gypsum as a Soil Amendment on Improved Hybrid Bermudagrass," In Proceedings of the 11 th International Symposium on Use and Management of CCBs; Vol.1, Jan. 1995; pp 10-1-10-7.

Carlson, C.W.; Hern, J.L.; Korcak, F..F.; Stout, W.L. "Manual for Applying Fluidized Bed Combustion Residue to Agricultural Lands," U.S. Department of Agriculture ARS, ARS-74; Aug. 1988.

Chapman, R.G.; Hengel, J.A.; Wilterdink, D.W. "Design Considerations for FGD Solids Disposal/Utilization at a Power Plant with Limited Space" In Proceedings of the 10th Symposium on Flue Gas Desulfurization; EPRI CS-5167, Vol. 2, May 1987; pp 10-41-1057.

Chern, W.S.; Hite, D.; Hitzhusen, F. "Analysis of the Welfare Impacts of Landfilling Coal FGD By-Product," In Proceedings of the 11th Annual International Pittsburgh Coal Conference; Pittsburgh, PA. Sept. 12-16, 1994; pp 431-436.

Clarke, L.B. Management of Residues from Flue Gas Desulphurisation Systems; IEA Coal Research: London, V-K-1993.

Collins, R.E.; Golden, D.M.; Luckevich, L.M. "The Gypsum Industry and FGD Gypsum Utilization," In Proceedings of the 11th International Symposium on Use and Management of Coal Combustion By-Products (CCBs); EPRI TR-104657-V1, Vol. 1, Jan. 1995; pp 231-23-10.

Conroy, A.; Duren, J.R.; Laslo, D. "FGD System Produces Commercial-Grade Gypsum," Power Engineering 1988, Oct., 35-38.

Cramers, P.; Doldersum, H.M.R.; Wilkinson, B.; Van Dierendonck, P. M.; Laurent, L. "The Kinetics of Uncatalyzed Sodium Sulfite Oxidation," Chem. Eng. Sci. 1993, 48 (5), 933-941. 
Dick, W.A.; Stehouwer, R.C.; Sutton, P. "Minespoil Amendment with Dry Flue Gas

Desulfurization By-Products: Plant Growth," J. Environ. Qual. 1995, 24, 861-869.

Dravo Lime Company and Ohio Edison/Penn Power. "Bruce Mansfield Power Plant: Gypsum Production Demonstration Project," brochure.

Eisele, T.C.; Kawatra, S.K. "Separation of the Components of Flue-Gas Scrubber Sludge by Froth Flotation," In Proceedings of the XIX International Mineral Processing Congress; San Francisco, CA, 1995.

Eisele, TC.; Rao, K.V.C.; Kawatra, S.K. "Cycloning and Froth Flotation of Scrubber Sludge for Pollution Prevention," Presented at the Engineering Foundation Conference on Technical Solutions for Pollution Prevention in the Mining and Mineral Processing Industries, Palm Coast, FL, Jan. 1995.

Electric Power Research Institute. "Flue Gas Desulfurization (FGD) Gypsum Utilization Guideline," EPRI RP-3176; Combustion By-Product Utilization Research 1993, 10 (4).

Electric Power Research Institute. "Land Application of Coal Combustion By-Products: Use in Agriculture and Land Reclamation," In EPRI Report Summary; June 30, 1995.

Ellison, W.; Hammer, E. "FGD-Gypsum Use Penetrates U.S. Wallboard Industry," Power 1988, Feb., 29-33.

Ellison, W.; Kappe J. "Utilization of Residuals from Flue Gas Desulfurization, " Environmental Progress 1986, 5 (3), 191-196.

Engert, H.J.; Kirchen, G.; Koslowski, T.; Lehmkamper, O. "Full Scale Experience with a New Process and High Quality Products Based on FGD Gypsum, ${ }^{n}$ In Proceedings of the 11th International Symposium on Use and Management of Coal Combustion By-Products (CCBs); EPRI TR-104657-V1, Vol. 1, Jan. 1995; pp 34-1-34-12.

Esche, M.; Glamser, J.H.; Rock, K.L. "A Lime Based FGD Process Utilizing Forced Oxidation to Produce Stable Gypsum By-Product," Combustion 1979, July, 22-26.

Forster, D.L. "Economic Analysis of FGD By-Product Use as an Agricultural Lime Substitute," In Proceedings of the 11th Annual International Pittsburgh Coal Conference; Pittsburgh, PA, Sept. 12-16, 1994; pp 437-442.

Fu, C.-C.; McCoy, B.J.; Smith, J.M. "Dynamic Analysis of Homogeneous Reactions in a Stirred Bubble Reactor: Oxidation of Sulfite," Chem. Eng. Sci. 1988, 43 (6), 1231-1242.

Hatch, R. "The Use of FGD Gypsum for the Manipulation of Soil Chemistry in the Agricultural and Remediation Markets," In Proceedings of the 3rd International Conference on FGD and Chemical Gypsum; Sept. 1993; pp 8-1-8-3. 
Hemmings, R.T.;Venta, G.J. "FGD Gypsum Utilization: Bridging the 'Two Solitudes'," In ACAA Supplemental Proceedings of the 11th International Symposium on Use and Management of Coal Combustion By-Products (CCBs); Orlando, FL, Jan. 15-19, 1995.

Ohio State University. "Land Application Uses for Dry FGD By-Products," Phase 1 Report; April 1993.

Ortech International Corporation. Proceedings of the 5th International Conference on FGD and Chemical Gypsum; Toronto, ON, Canada, May 11-14, 1997.

Ortech International Corporation. Proceedings of the 4th International Conference on FGD and Chemical Gypsum, Toronto, ON, Canada, May 17-18, 1995.

Ortech International Corporation. Proceedings of the 3rd International Conference on FGD and Chemical Gypsum, Torontc, ON, Canada, Sept. 26-28, 1993.

Ortech International Corporation. Proceedings of the 2nd International Conference on FGD and Chemical Gypsum, Torontc, ON, Canada, May 12-15, 1991.

Ortech Corporation. Proceedings of the 1st International Conference on FGD and Chemical Gypsum, Toronto, ON, Canada, 1989.

Proceedings of the Coal Combustion By-Products Associated with Coal Mining-Interactive Forum; Southern Illinois University at Carbondale, Oct. 29-31, 1996.

Proceedings of the 1995 International Ash Utilization Symposium; University of Kentucky Center for Applied Energy Research and the journal Fuel, Oct. 23-25, 1995.

Santhanam, C. J.; Lunt, R.R.; Cooper, C.B.; Klimschmidt, D.E.; Bodek, I.; Tucker, W.A.; Ullrich, C.R. Flue Gas Cleaning Wastes Disposal and Utilization; Noyes Data Corporation: Park Ridge, NJ, 1981.

Sawyer, D.T.; Seo, E.D. "Determination of Sulfur Dioxide in Solution by Anodic Voltammetry and by U.V. Spectrophotometry," Journal of Electroanalytical Chemistry 1964, 7, 184-189.

Shahandeh, H.; Sumner, M.E. "Establishment of Vegetation on By-Product Gypsum Materials," J. Environ. Qual. 1993, 22.. 57-61.

Steffan, P.; Golden, D. "FGD Gypsum Utilization-Survey of Current Practices and Assessment of Market Potential," In Proceedings of the 2nd International Conference on FGD and Chemical Gypsum, Toronto, ON, Canada, May 12-15, 1991; Ortech International Corporation.

U.S. Department of the Interior. Flue Gas Desulfurization and Industrial Minerals $-A$ Bibliography; Bureau of Mines Special Publication, Oct. 1993.

Warren, C.J. " Some Limitations of Sluiced Fly Ash as a Liming Material for Acidic Soils," Waste Management and Research 1992, 10, 317-327. 
APPENDIX C EQUIPMENT AND COST ESTIMATES
FOR PROCESS SCALE-UP 


\section{DRAYU UTE Banghin

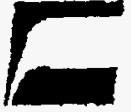

May 30, 1997

Charlie Bullinger

Cooperative Power

Coal Creek Station

P.O. Box 780

Underwood, ND 58576-9759

Subject: Cost Estimate for Gypsum Production at Coal Creek

Dear Charlie:

Using the fuel chemistry and the plant operating data you supplied, I put together the attached mass balance for the oxidation facility. Also attached is a flow diagram and an estirnate of the oxidation facility costs.

The estimate is fairly conservative. Some of the assumptions I made were: .

- The $\mathrm{CO}_{2}$ content of the solids was set equal to $2 \%$. This is a very high number for a mag-lime scrubber. It is however the only $\mathrm{CO}_{2}$ result I have from real scrubber solids. The sample was taiken during the first week of testing the nag-lime process. The sulfuric acid consumption is directly related to this number. Typical $\mathrm{CO}_{2}$ 's for $\mathrm{Mg}$-lime scrubbers are 6 to 1.2. I would expect the acid consumption to be less than this spreadsheet is calculatizg.

- The oxidation air required :or the process calculates to 12,500 scfin based on $\mathrm{SO}_{2}$ in the inlet gas. The 15,000 sufin compressor was specified to better meet the demands when a sulfur spike is seen due to inconsistent coal quality. The compressor and 


\section{$E$}

Charlie Bullinger

May 30, 1997

Page 2 of 3

oxidation tower may be greatiy oversized due to natural oxidation in the scrubber. Microscope pictures of the scrubber solids show crystals with a structure typical of gypsum not calcium sulfite. The samples were submitted to our lab to determine the amount of sulfite oxidation in the crystals. To date, we do not have the results. If natural oxidation is high the size of the tower and compressor can be drastically reduced.

- The belt filter is sized to produce $10 \%$ moisture in the product gypsum. If $20 \%$ moisture is acceptable the belt filter could be much smaller (approximately $40 \%$ ). This size reduction would greatly reduce the cost of the most expensive piece of equipment in the process.

- The scrubbers will continue to operate at $15-20 \%$ solids. This is necessary for the proper operation of the oxidizer.

It is very important at this time to get representative samples and analyze them for $\mathrm{CO}_{2}$, $S_{\text {wet }}$ and sulfite to nail down the oxidation plant size.

The plant layout would start with a catch basin in the bottom of each scrubber module. These catch basins would collect downcoming low pH scrubbing liquor and deliver it to a pump head tank. This tank would gravity overflow back into the recycle tanks. The oxidizer would be fed by pumping slumy form this head tank to the top of the oxidizer. The oxidizer will operate at a pH of $5.0-5.6 . \mathrm{H}_{2} \mathrm{SO}$, will be added to achieve this. There will be two oxidizers, one for each unit. These oxidizers will be located in or near the scrubber buildings. The oxidized slurries from both units will be pumped to a centralized filter building. The gypsum siurry will be bydrocloned to separate the fines. The HC overflow will go to your existing pond where the fines can settle. The clear pand liquor can be retumed as process water. The thickened, (HCUF) gypsum will be fed to a belt filter and dewatered. The filtrate becomes process makeup water and the gypsum is either trucked or conveyed to storage. 
Charlie Bullinger

May 30, 1997

Page 3 of 3

The $\mathrm{H}_{2} \mathrm{SO}_{4}$ will be held in a storage tank near or in the centralized filter building and delivered to the oxidizers. The $\mathrm{H}_{2} \mathrm{SO}_{4}$ will need to be diluted with about 5-10 gpm of water before it enters the top of the oxidizer. This is to prevent a localized low $\mathrm{pH}$ and provide better acid mixing at the top of the oxidizer.

This plant will produce aproximately 210,000 tons of gypsum per year based on a 91\% capacity factor and $97 \% \mathrm{SO}_{2}$ reploval of the entire gas stream. The bypass is closed to allow for this much gypsum prodiction.

The attached estimate is a first flass and can be improved on once the solid and liquid phase chemistries become stable. The cost factors used are typical for most of the U.S. The North Dakota factor may neei to be added for improved insulation or heat tracing. If you bave any questions please call Kevin Smith 777-0715 as my last day is May 30"t.

Good luck,

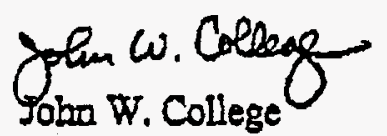

Manager of Technology

Attaciments

cc: M. Babu

R. Forsythe

R. Todd

K. Smith

D. Sterant 
Coal Creek Station

Equipment List for Oxidation Plant and Gypsum Filtering

\begin{tabular}{|c|c|c|c|c|c|c|c|c|c|}
\hline & Quantity & Spares & Design Hasis & Size & Mhaterial & $\begin{array}{c}\text { Cost Per } \\
\text { Unit }\end{array}$ & Total Cust & $\begin{array}{c}\text { Const. Const } \\
\text { Inufex }\end{array}$ & $\begin{array}{l}\text { Installed } \\
\text { Cost }\end{array}$ \\
\hline $\begin{array}{l}\text { Downcomer } \\
\text { Surge Tank }\end{array}$ & 2 & $\begin{array}{l}\text { (onthimit) } \\
\text { no spans }\end{array}$ & $\begin{array}{l}75 \text { mínule residence } \\
\text { (always overflowing) }\end{array}$ & $\begin{array}{c}5^{\prime}-d-10^{2}=b \\
1500 \text { gallon }\end{array}$ & FRP & $\$ 5,000$ & $\$ 5,000$ & 25 & 512,500 \\
\hline $\begin{array}{l}\text { Oxidizer Feod } \\
\text { Pump }\end{array}$ & 2 & $\begin{array}{l}\text { (onefumit) } \\
\text { no spares }\end{array}$ & $\begin{array}{l}210 \mathrm{gmm} \\
100^{\circ} \text { todh }\end{array}$ & $\begin{array}{l}\text { 1/3 CAH } \\
\text { Warnan }\end{array}$ & $\begin{array}{l}\text { Carbon } \\
\text { Sicel } \\
\text { Rubber } \\
\text { lined }\end{array}$ & $\$ 7,500$ & $\$ 15,000$ & 2.5 & $\$ 37,500$ \\
\hline Oxidizertines & 2 & $\begin{array}{l}\text { (onu/unit) } \\
\text { no spares }\end{array}$ & $\begin{array}{c}2.5 \text { hr residence timue } \\
20 \% 6 \text { gas cxpansion } \\
2 \text { A freebourd }\end{array}$ & $\begin{array}{l}12^{\prime}=d \\
50^{\prime}=4\end{array}$ & FrP & $\$ 91,800$ & $\$ 183,600$ & 2.5 & $\$ 159,000$ \\
\hline $\begin{array}{c}\text { Air } \\
\text { Compiressur }\end{array}$ & 1 & $\begin{array}{l}\text { (unchunit) } \\
\text { no spares }\end{array}$ & $\begin{array}{c}15,000 \text { SCFM } \\
30 \mathrm{psi}\end{array}$ & - & - & $\$ 430,000$ & $\$ 430.001 !$ & 2.0 & $\$ 860,000$ \\
\hline $\begin{array}{l}\text { Sulfuric Acid } \\
\text { Storagc Tunk }\end{array}$ & $\mathbf{1}$ & no spares & 20,(100 gallons/wk & 25,000 gallons & $\begin{array}{c}\text { Carbon } \\
\text { Stcel } \\
\end{array}$ & $\$ 25,000$ & $\$ 25,000$ & 2.5 & $\$ 62,500$ \\
\hline $\begin{array}{c}\text { Oxidizer Acid } \\
\text { Pump }\end{array}$ & 2 & $\begin{array}{l}\text { (one/unil) } \\
\text { no spares }\end{array}$ & I enm & $\begin{array}{l}\text { Positive } \\
\text { Jisplacement }\end{array}$ & $\begin{array}{c}\text { Stainless } \\
\text { Steel }\end{array}$ & $\$ 6,000$ & $\$ 12,000$ & 2.0 & $\$ 24,04 K 0$ \\
\hline $\begin{array}{l}\text { Oxidizer } \\
\text { Producl Pump }\end{array}$ & 2 & $\begin{array}{l}\text { (ondiuni) } \\
\text { no spares }\end{array}$ & $\begin{array}{l}210 \mathrm{gpm} \\
100^{\circ} \mathrm{kh}\end{array}$ & $\begin{array}{l}4 / 3 \mathrm{CAH} \\
\text { Warman }\end{array}$ & $\begin{array}{l}\text { Curbon } \\
\text { Sicel } \\
\text { Ruiblier } \\
\text { Lined } \\
\end{array}$ & $\$ 7,500$ & 815,000 & 2.5 & $\$ 37,500$ \\
\hline IIydroclones & 4 & 1 spare & $\begin{array}{c}100-130 \text { gpm cach } \\
30 \mathrm{psi}\end{array}$ & $6^{\circ}-$ Warman & $\begin{array}{l}\text { Carbon } \\
\text { Skcel } \\
\text { Rubbri } \\
\text { Lined } \\
\end{array}$ & $\$ 8,500$ & $\$ 42,500$ & 2.0 & $\$ 85,000$ \\
\hline $\begin{array}{l}\text { Belt Pillor } \\
\text { System }\end{array}$ & $\mathbf{1}$ & no sparts & $135 \mathrm{lbs} / \mathrm{A}^{2} / \mathrm{hr}$ & $\begin{array}{c}3 \text { meter } \times 13 \\
\text { meter Eimco } \\
\text { Model 2M31 } \\
\text { Extractor } \\
\end{array}$ & SS & $\$ 700,000$ & $\$ 700,000$ & 20 & $\$ 1,400,000$ \\
\hline Tolals & & & & & & & $\$ 1,428,000$ & & $\$ 2,978,000$ \\
\hline
\end{tabular}




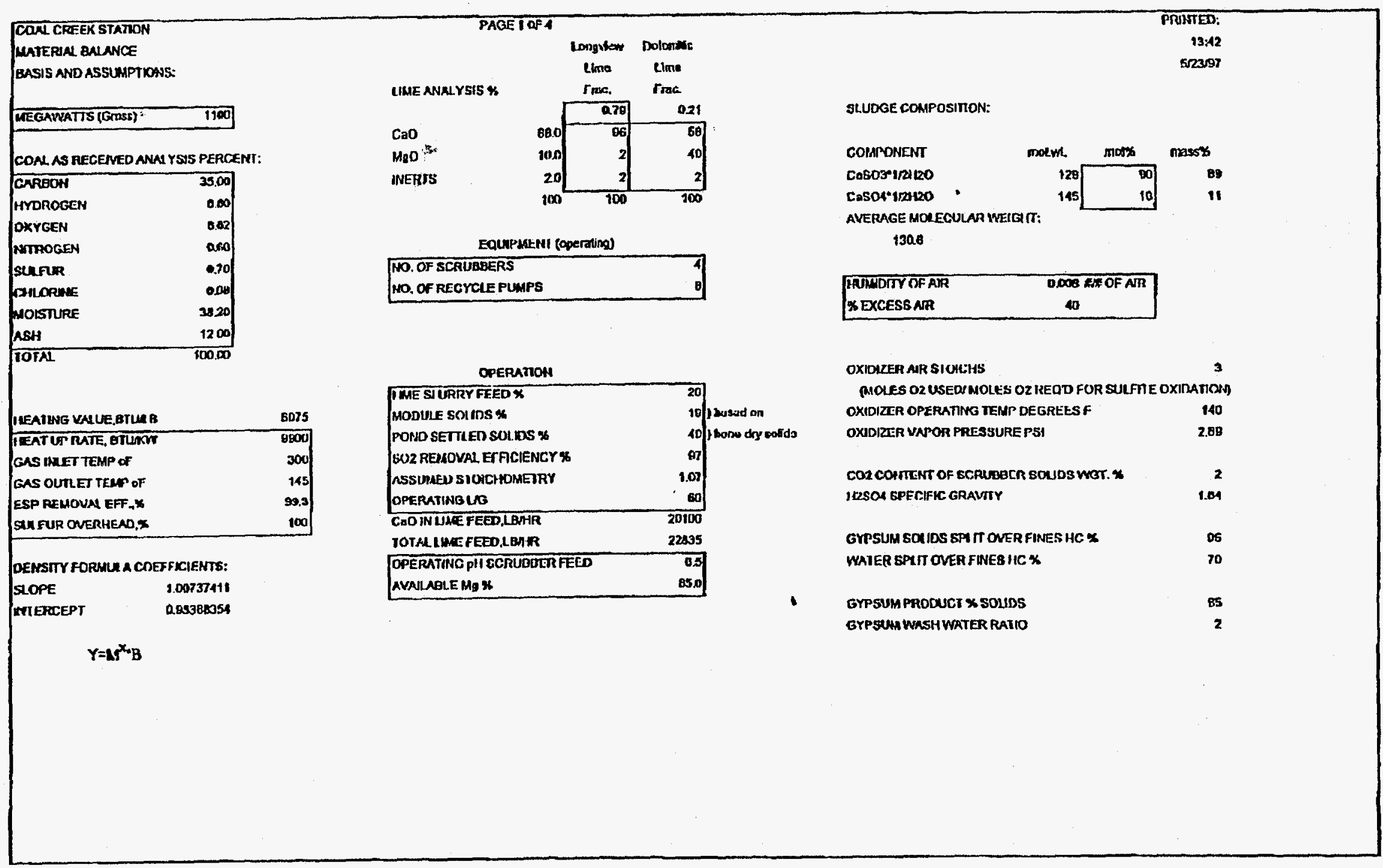


,

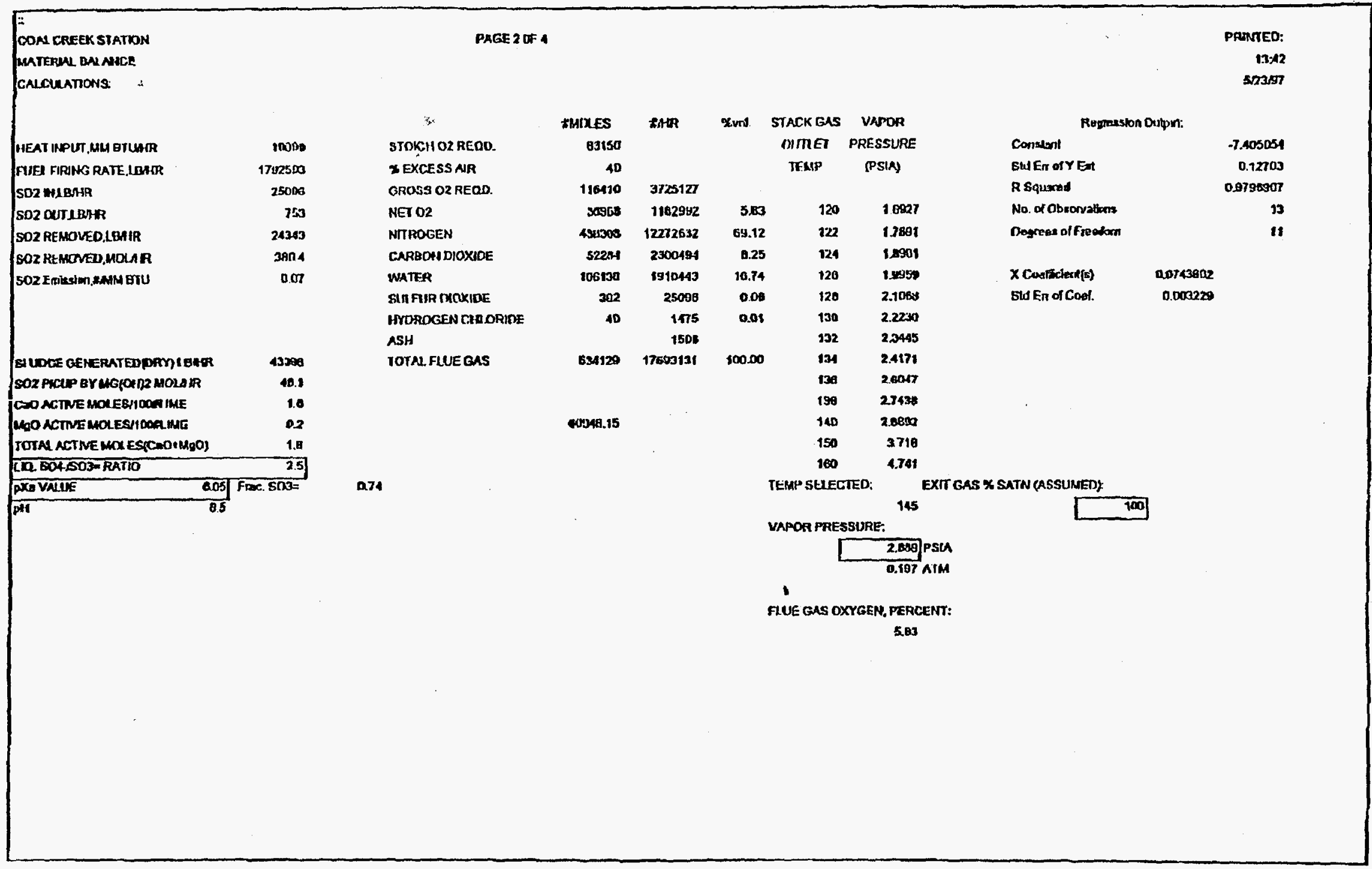




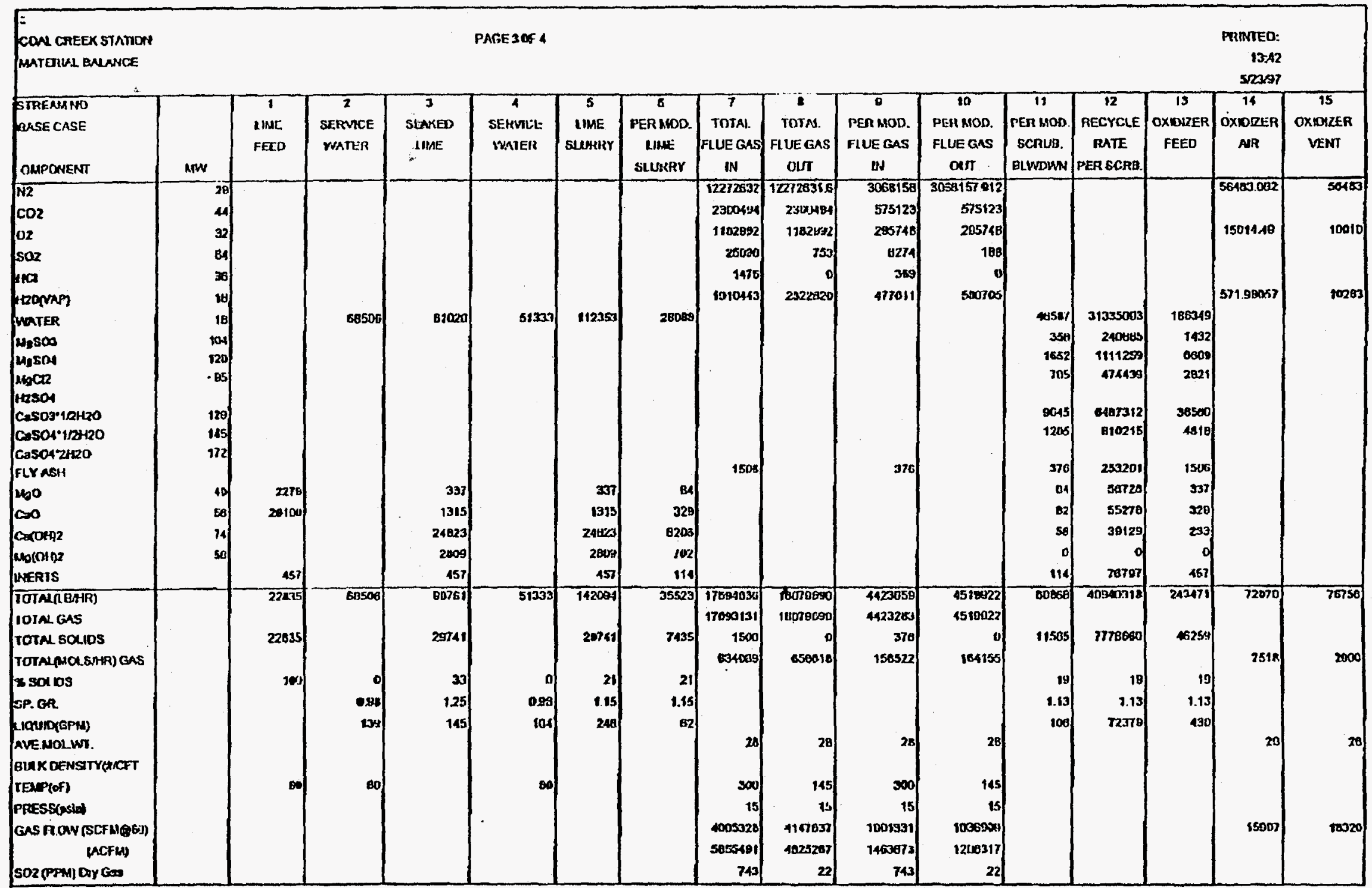




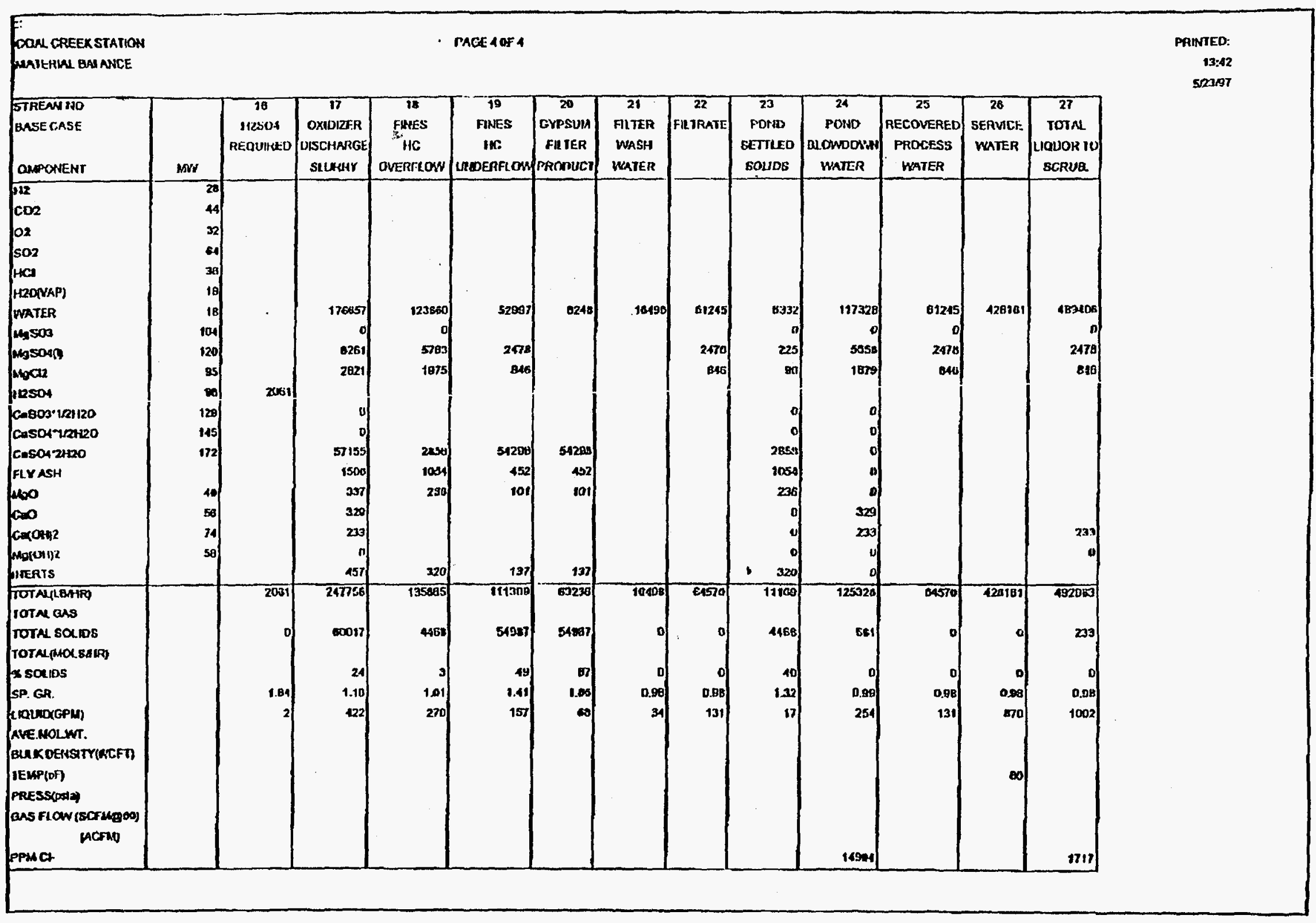




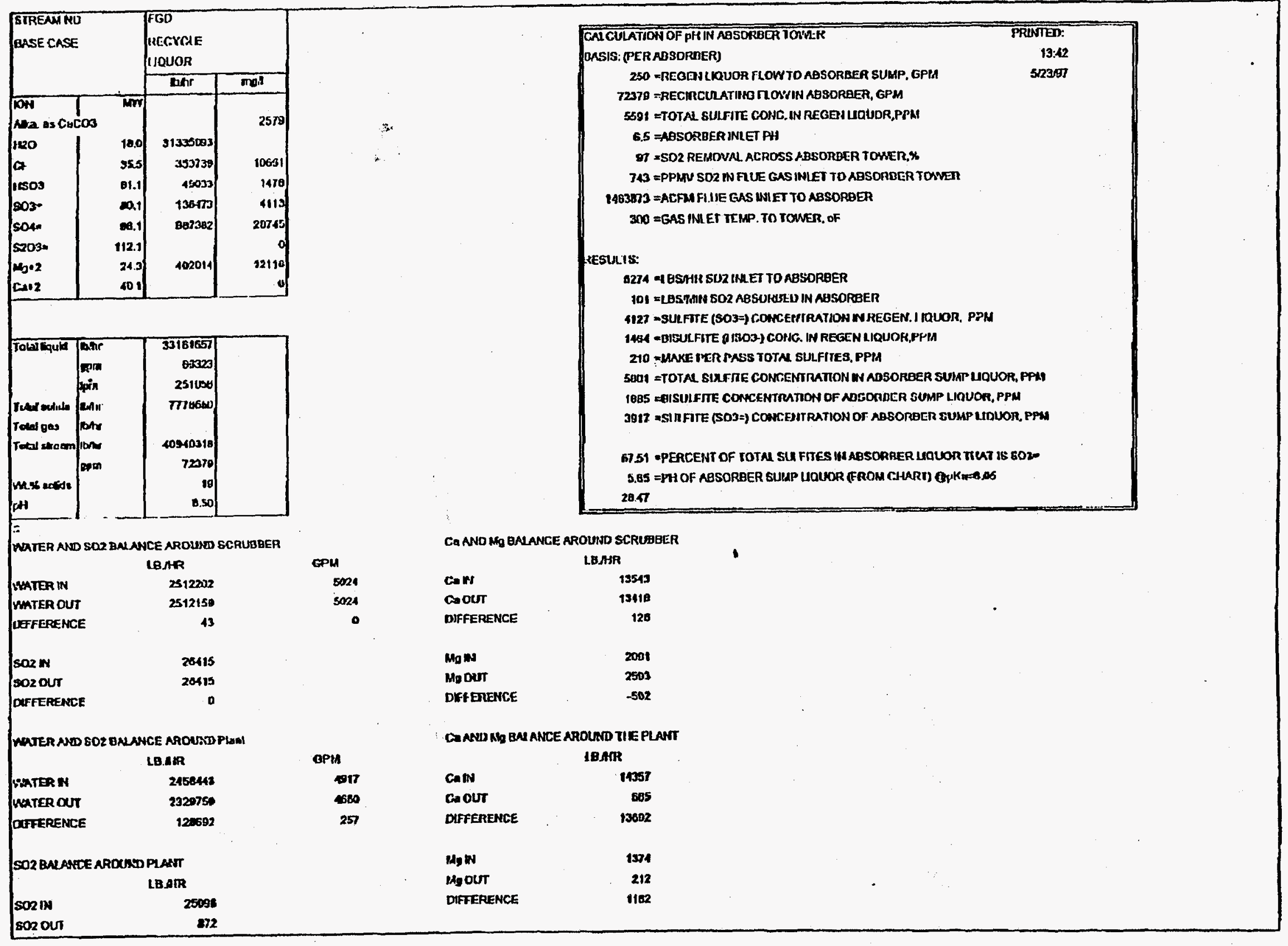




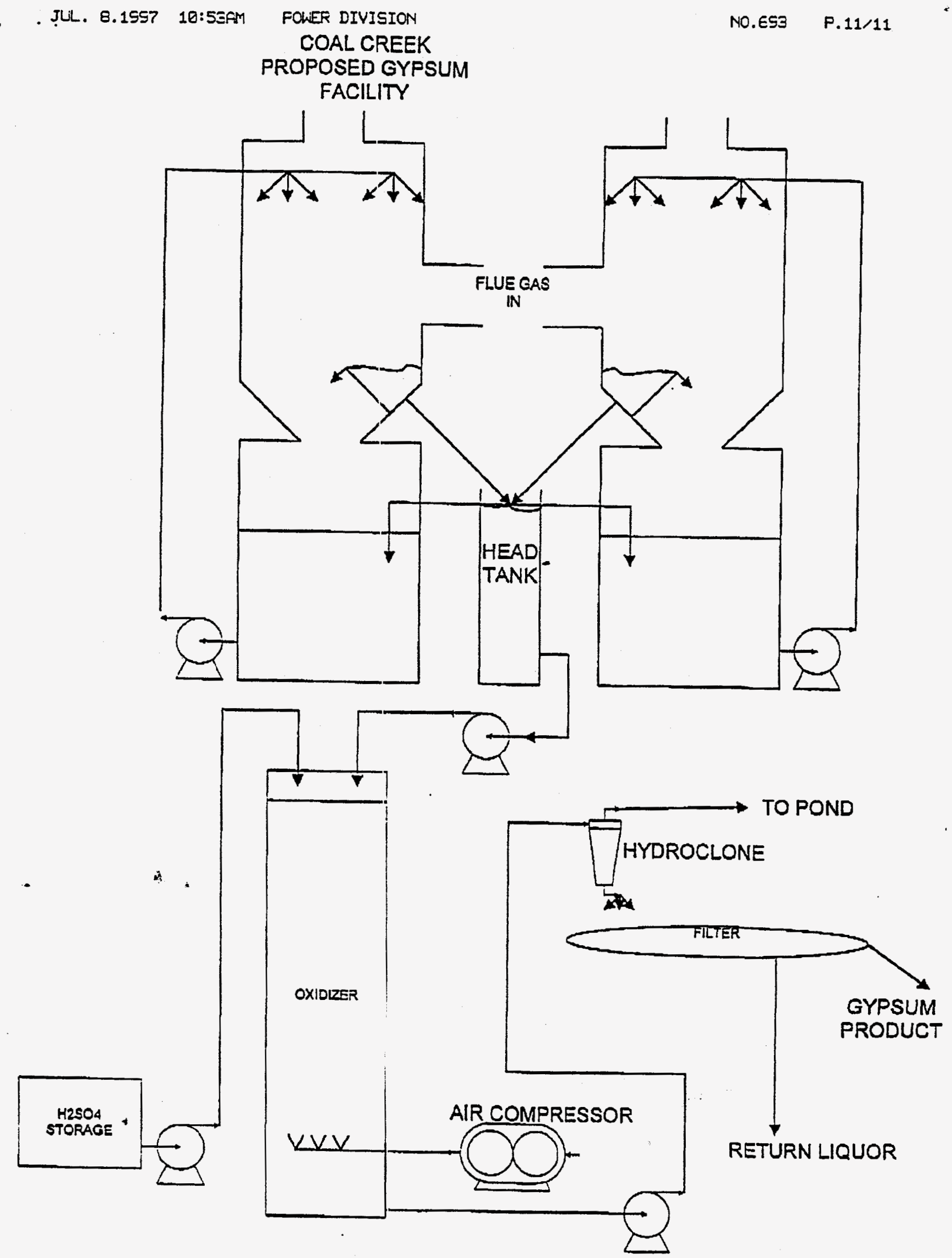

